\title{
(5-Hydroxy-4-oxo-2-styryl-4H-pyridin-1-yl)-acetic Acid Derivatives as Multifunctional Aldose Reductase Inhibitors
}

\author{
Huan Chen, Xin Zhang, Xiaonan Zhang, Wenchao Liu, Yanqi Lei, Changjin Zhu * and Bing Ma * \\ School of Chemistry and Chemical Engineering, Beijing Institute of Technology, Beijing 100081, China; \\ ch13264138964@163.com (H.C.); zx15811458104@163.com (X.Z.); zhangxiaonan965@163.com (X.Z.); \\ liuwhhh@163.com (W.L.); 15313252939@163.com (Y.L.) \\ * Correspondence: zcj@bit.edu.cn (C.Z.); mabing@bit.edu.cn (B.M.); Tel.: +86-010-68918506 (C.Z. \& B.M.)
}

Academic Editors: Jiang Wang, Liang-Ren Zhang, Peng Zhan, Qi-Dong You, Tian-Miao Ou and Xiao-Yun Lu

Received: 5 October 2020; Accepted: 3 November 2020; Published: 4 November 2020

\begin{abstract}
As rate-limited enzyme of polyol pathway, aldose reductase (ALR2) is one of the key inhibitory targets for alleviating diabetic complications. To reduce the toxic side effects of the inhibitors and to decrease the level of oxidative stress, the inhibitory selectivity towards ALR2 against detoxicating aldehyde reductase (ALR1) and antioxidant activity are included in the design of multifunctional ALR2 inhibitors. Hydroxypyridinone derivatives were designed, synthesized and evaluated their inhibitory behavior and antioxidant activity. Notably, $\{2-[2-(3,4-d i h y d r o x y-p h e n y l)-v i n y l]-5-h y d r o x y-4-o x o-4 H$-pyridin-1-yl\}-acetic acid (7l) was the most potent, with $\mathrm{IC}_{50}$ values of $0.789 \mu \mathrm{M}$. Moreover, 71 showed excellent selectivity towards ALR2 with selectivity index 25.23, which was much higher than that of eparlestat (17.37), the positive control. More significantly, $7 \mathrm{l}$ performed powerful antioxidative action. At a concentration of $1 \mu \mathrm{M}$, phenolic compounds 71 scavenged DPPH radical with an inhibitory rate of $41.48 \%$, which was much higher than that of the well-known antioxidant Trolox, at $11.89 \%$. Besides, 71 remarkably suppressed lipid peroxidation with a rate of $88.76 \%$ at a concentration of $100 \mu \mathrm{M}$. The binding mode derived from molecular docking proved that the derivatives were tightly bound to the activate site, suggesting strongly inhibitory action of derivatives against ALR2. Therefore, these results provided an achievement of multifunctional ALR2 inhibitors capable with potency for both selective ALR2 inhibition and as antioxidants.
\end{abstract}

Keywords: aldose reductase inhibitors; antioxidant activity; pyridinones derivatives; molecular docking

\section{Introduction}

Diabetes mellitus (DM) is a metabolic disorder resulting from defects in insulin secretion, insulin action, or both. Accompanied by injury, dysfunction and organ failure, diabetic complications, which induced by long-term hypoglycaemia, are recognized as the main causes of morbidity and mortality in diabetic patients [1,2]. In the polyol pathway, large amounts of evidence proved that the overproduction of sorbitol and increased level of oxidative stress are the crucial reasons accelerating process of diabetic complications [3-5].

As the first and rate-determining enzyme in the polyol pathway, aldose reductase (ALR2, EC 1.1.1.21) reduces glucose into sorbitol in the presence of nicotinamide adenine dinucleotide phosphate (NADPH) [6-9]. (Figure 1) Subsequently, the NAD ${ }^{+}$-dependent sorbitol dehydrogenase oxidizes the intermediate sorbitol to fructose. Under normal condition, most of the cellular glucose is converted into glucose 6-phosphate and metabolized by hexokinase in glycolytic pathway $[10,11]$. Under hypoglycemia, however, due to the saturation of hexokinase, excess glucose is then metabolized 
by the polyol pathway, leading to accumulation of sorbitol and depletion in NADPH and NAD ${ }^{+}$[9]. Since the high polarity of sorbitol blocks easy penetration through membranes and subsequent removal from tissues by diffusion, the accumulation of sorbitol eventually leads to osmotic imbalance, cell swelling, and membrane permeability changes [2]. Simultaneously, the disturbance of NADPH/NADP ${ }^{+}$ and $\mathrm{NAD}^{+} / \mathrm{NADH}$ ratios alter cellular redox potentials, resulting in the onset of hyperglycemic oxidative stress caused by both increased accumulation of reactive oxygen species (ROS) and weakened antioxidant defense [12]. In addition, associated with the elevation of polyol pathway, the increased level of fructose also accelerates the intracellular formation of advanced glycation end products and facilitates the further generation of ROS [13]. Although greatly increased levels of ROS lead to significant cellular damage when the antioxidant defenses are overwhelmed, the antioxidants may decrease the ROS concentration, and lower the oxidative stress of chronic diseases [14,15]. Therefore, to eliminate the abnormal accumulation of sorbitol and to alleviate the injury related to oxidative stress, the ALR2 inhibition and further reduction in the polyol pathway of glucose metabolism are attractive methods able to reverse or retard the progression of diabetic complications [16]. Due to pharmacokinetic drawbacks, adverse side effects or low efficacy, however, a number of ALR2 inhibitors (ARIs) in class of carboxylic acid derivatives have failed. Poor selectivity over detoxicating aldehyde reductase (ALR1, EC 1.1.1.2), which specifically metabolizing toxic aldehydes, is considered as one of the critical reasons for the side effects $[17,18]$. Therefore, selective inhibition of ALR2 is desirable in the design of new ARIs. Although ARL2 differential inhibitors were promising to selectively inhibit the reduction of hemiacetal aldose rather than that of toxic aldehyde [19], regarding its significant role in the detoxification of ALR1, selective ALR2 inhibition was still the major topic focused on ARI research [20-23].

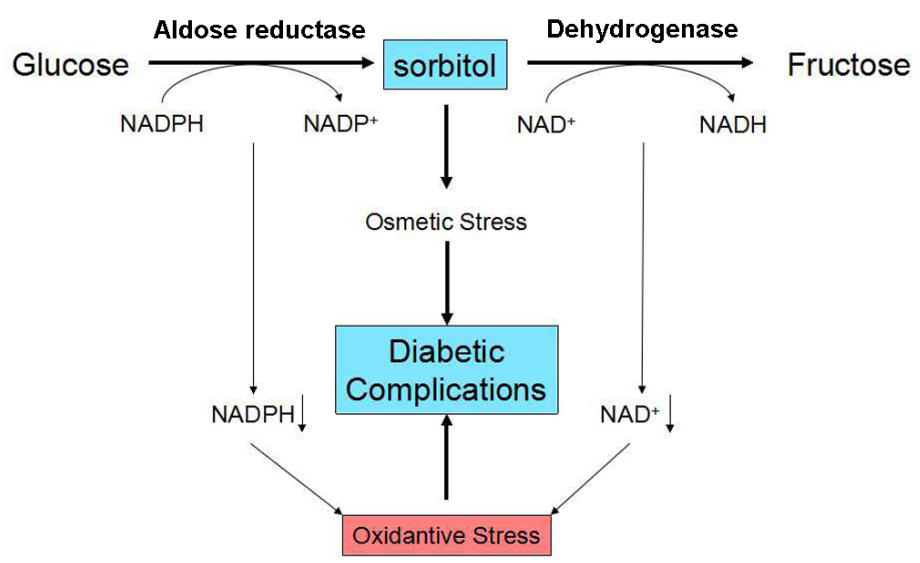

Figure 1. Polyol pathway and pathogenesis of diabetic complications.

Endowed with potent ALR2 inhibitory activity, compounds with carboxylic acid moiety were mostly developed among synthetic ARIs. (4-Oxo-2-thioxothiazolidin-3-yl) acetic acid [20], rhodanine-3-hippuric acid derivatives [21], 2-phenoxypyrido[3,2-b]pyrazin-3(4H)-one [22] and 2-(3-oxo-2H-[1,2,4]triazino[5,6-b]indol-5(3H)-yl) acetic acid [23] showed high inhibitory efficacy with attractive $\mathrm{IC}_{50}$ values $(23 \sim 42 \mathrm{nM})$, suggesting that the carboxylic group is the key moiety preforming outstanding activity. However, the antioxidant properties of these inhibitors need to be improved.

Served as antivirus [24,25], anti-Alzheimer's disease [26] and even anti-diabetes [27-30] agents, synthetic 3-hydroxy-4(1H)-pyridinone derivatives may have potential for the development of ARI. Interestingly, a large amount of evidence has proven that synthetic 3-hydroxy-4(1H)-pyridinone derivatives exhibited remarkable activity of antioxidant, and they ameliorated oxidative stress by directly neutralizing superoxide anions [31-33]. Notably, novel 2-styryl-1H-pyridin-4-ones showed significant radical scavenging activity [34], illustrating that these compounds may be the desirable candidates with antioxidant capacity fighting against oxidative stress. Thus, combining ALR2 inhibition with antioxidant action, hydroxyl pyridinones is favorable to be designed as 
antioxidative core of carbonxylic multifunctional ARI. Unfortunately, the inhibitory action of hydroxyl pyridinones against ALR2 remained undiscovered. In the present study, a new series of (5-hydroxy-4-oxo-2-styryl-4H-pyridin-1-yl)-acetic acid derivatives were designed to verify their ALR2 inhibitory actions and antioxidant behaviors.

\section{Results and Discussion}

\subsection{Chemistry}

The synthetic route of the (5-hydroxy-4-oxo-2-styryl-4H-pyridin-1-yl)-acetic acid derivatives (7) is outlined in Scheme 1. From the starting material of commercial available kojic acid, critical intermediate 3 was prepared by benzyl protection and followed chlorination. Different styryl side chains were readily linked to the C2-position of pyranones, to obtain 5-benzyloxy-2-styryl-pyran-4-ones (5) by Wittig reaction. Intermediates 6 with carboxylic group were obtained by the substitution of glycine, followed by the deprotection of benzyl group by hydrochloric acid to afford the target compounds $7 \mathbf{a}-\mathbf{i}$. In addition, the intermediates $\mathbf{6} \mathbf{d}$,e were reacted with $\mathrm{BBr}_{3}$ to yield the desirable phenolic products $7 \mathbf{k}-\mathbf{1}$.<smiles>CC(C)(C)Cc1cc(=O)c(OCc2ccccc2)co1</smiles><smiles></smiles>

a: $\mathrm{R}_{1}=\mathrm{H}$

b: $\mathrm{R}_{1}=p-\mathrm{Me}$

c: $\mathrm{R}_{1}=p-\mathrm{tBu}$

$\mathrm{d}: \mathrm{R}_{1}=p-\mathrm{OMe}$

$\mathrm{e}: \mathrm{R}_{1}=m, p-(\mathrm{OMe})_{2}$

$\mathrm{f:} \mathrm{R}_{1}=p-\mathrm{F}$

$\mathrm{g}: \mathrm{R}_{1}=m, p-\mathrm{F}_{2}$

$\mathrm{h}: \mathrm{R}_{1}=p-\mathrm{CF}_{3}$

i: $\mathrm{R}_{1}=p-\mathrm{SO}_{2} \mathrm{Me}$

$\mathrm{j}: \mathrm{R}_{1}=p-\mathrm{NHAC}$

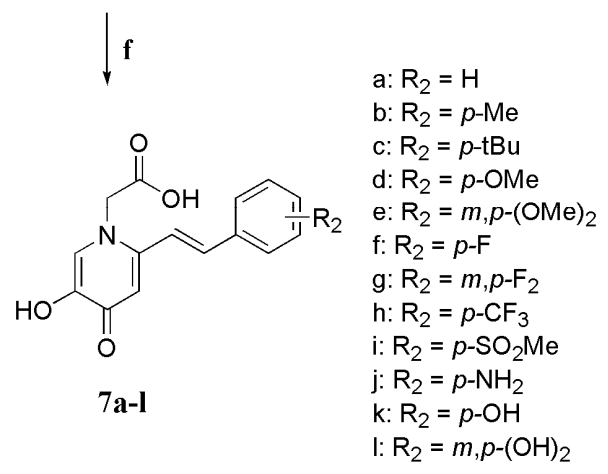

Scheme 1. Reagents and conditions: (a) $\mathrm{BnBr}, \mathrm{NaOH}, i-\mathrm{PrOH}, \mathrm{H}_{2} \mathrm{O}$, reflux, $5 \mathrm{~h}, 70 \%$; (b) $\mathrm{SOCl}_{2}, \mathrm{DCM}$, r.t., 3 h, 74\%; (c) $\mathrm{PPh}_{3}, \mathrm{CHCl}_{3}$, reflux, 24 h, 43\%; (d) benzaldehyde, DCM, 50\% NaOH, r.t. 2 h, 25 87\%; (e) glycine, $\mathrm{NaOH}, i-\mathrm{PrOH}, \mathrm{H}_{2} \mathrm{O}$, reflux, $36 \mathrm{~h}, 12 \sim 27 \%$; (f) $6 \mathrm{M} \mathrm{HCl}$, reflux, 24 h or $\mathrm{BBr}_{3}, \mathrm{DCM}$, r.t., overnight, $29 \sim 88 \%$.

The synthetic procedure preparing intermediate 5 from kojic acid was referenced by reported method [34]. Due to the poor solution in organic solvent, glycine was inactive in the substitution. To increase reactiveness of glycine, the optimization of reaction conditions preparing 6 was performed by reacting different equimolar quantities of intermediate 5 and glycine, in the presence of solvents of variable water $/ i$-PrOH proportions. The optimum conditions were finally found by refluxing the reaction mixture with a high ratio of glycine as reactant and high ratio of water as solvent in the presence of $\mathrm{NaOH}$. The structures of novel pyridinone-based carboxylic derivatives were confirmed by 
using spectral data ${ }^{1} \mathrm{H}$ NMR, ${ }^{13} \mathrm{C}$ NMR and HRMS. Among the title compounds, $\mathbf{7 d}$ was taken as a representative compound for spectroscopic discussion. In the ${ }^{1} \mathrm{H}$ NMR spectrum of newly synthesized compound 7d, a singlet was observed at $\delta 5.10(\mathrm{~s}, 2 \mathrm{H})$ corresponding to $\mathrm{CH}_{2}$ located in N-substituted acetic acid, proving that carbonxylic group was introduced into pyridinone core. Coincident with result of ${ }^{1} \mathrm{H}$ NMR, signal in ${ }^{13} \mathrm{C}$ NMR of $7 \mathbf{d}$ was detected at $\delta 160.71$ corresponding to $\mathrm{C}=\mathrm{O}$ of carbonxylic group. In addition, the compound was confirmed by HRMS in negative mode. All other derivatives exhibit identical results.

\subsection{Enzyme Inhibition}

All the title compounds were tested for their inhibitory activity against human recombinant ALR2. In order to investigate the selectivity toward to ALR2 against ALR1, only derivatives active in ALR2 inhibition were then subjected to evaluate for their inhibitory effect on human recombinant ALR1. The results of inhibitory activity against the enzymes were summarized in Table 1.

Table 1. Enzyme inhibition activity of 5-hydroxy-4-oxo-2-styryl-4H-pyridinone derivatives.

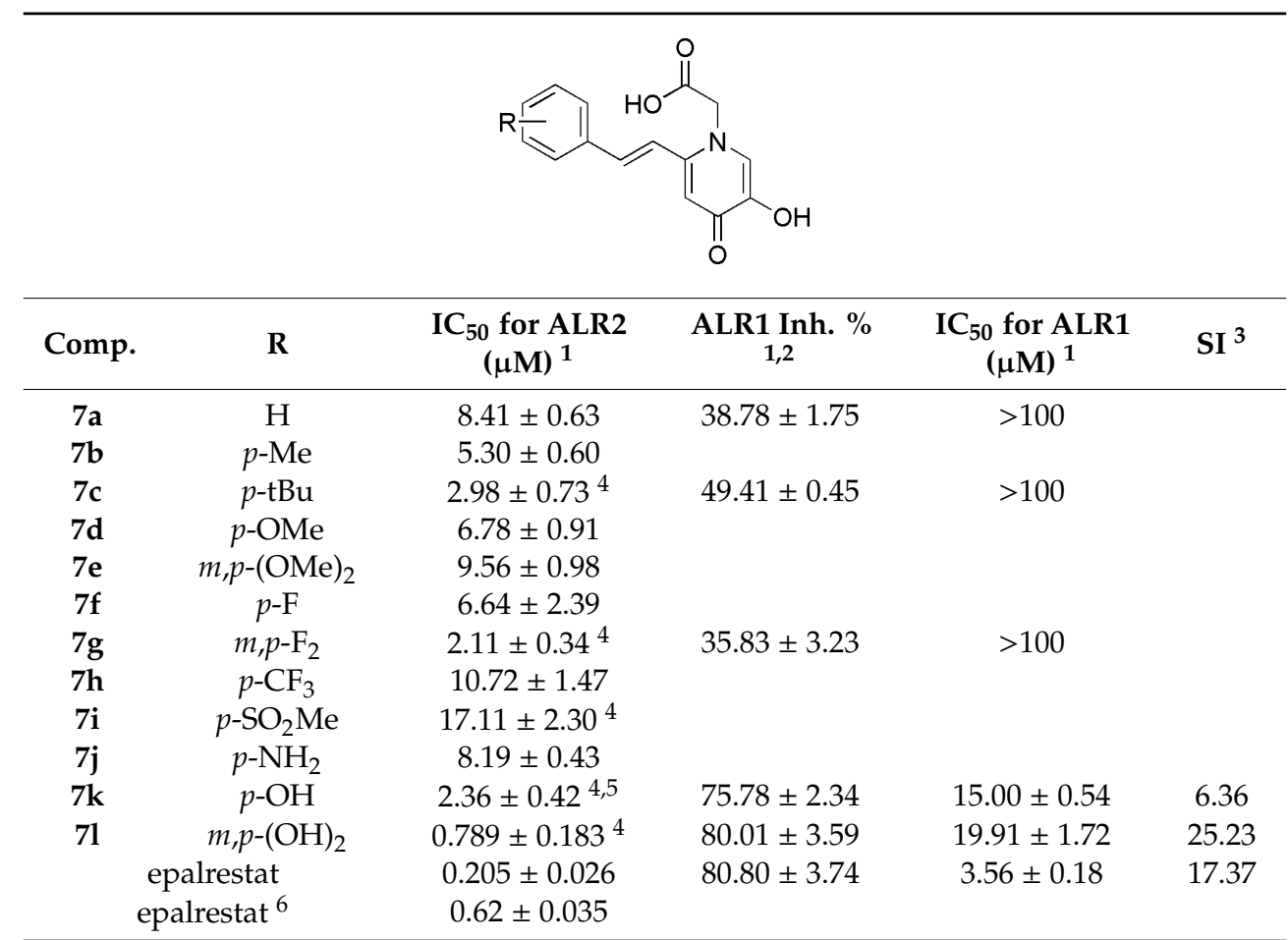

${ }^{1} \mathrm{n}=3 ;^{2}$ Tested in concentration of $100 \mu \mathrm{M} ;{ }^{3}$ Defined as IC ${ }_{50}$ [ALR1]: $\mathrm{IC}_{50}$ [ALR2]; ${ }^{4}$ One-way ANOVA followed by Tukey multiple comparison test, $p<0.05$ compared to $7 \mathbf{a}^{5}{ }^{5}$ Tukey test, $p<0.05$ compared to $7 \mathbf{d}^{6}{ }^{6}$ Reported by Iqbal Z. et al. [35].

The results demonstrated that most of 5-hydroxy-2-styryl- $1 H$-pyridin-4-ones derivatives showed good to excellent inhibitory activity against ALR2 with $\mathrm{IC}_{50}$ values varying from 0.789 to $17.11 \mu \mathrm{M}$. The structure-activity relationship revealed that the modification of some substituents on aromatic ring located in 2-styryl side chain could dramatically $(p<0.05)$ alter the inhibitory activity $(7 \mathbf{c}, 7 \mathbf{g}, 7 \mathbf{i}$ and 7k-1). Notably, \{2-[2-(3,4-dihydroxy-phenyl)-vinyl]-5-hydroxy-4-oxo-4H-pyridin-1-yl\}-acetic acid (71) exhibited the most potent inhibitory effect among the tested analogs $\left(\mathrm{IC}_{50}=0.789 \mu \mathrm{M}\right)$. In addition, compound $7 \mathrm{k}$ embodied with the $\mathrm{C} 2$-vinylphenolic group had much better inhibitory activity than that with C2-vinyl-methoxy-phenylic one (7d), demonstrating that the introduction of phenolic group enhanced the activity significantly $(p<0.05)$. Interestingly, the compounds with electronic-withdrawing groups at the phenyl group of the C2-styryl residues were less effective in the ALR2 inhibition rather than that with electronic-donating groups. Indeed, substituted with methanesulfonyl group at aromatic 
ring of the side chain $(\mathbf{7 i})$, the inhibitory activity decreased greatly $(p<0.05)$ compared to that of $7 \mathbf{a}$. However, the inhibitory activity was strengthened due to the increasing hydrophobicity of the alkyl group at C2-styryl $(\mathbf{7} \mathbf{c}>\mathbf{7 b}>\mathbf{7 a})$. In this case, the $\mathrm{IC}_{50}$ value of epalrestat, which served as a positive ARI, was comparable to the one reported under similar experimental conditions [35], ensuring the validity of the tests.

To estimate the selectivity, the title compounds which presented preferable activity of ALR2 inhibition $\left(\mathrm{IC}_{50} \leq 5 \mu \mathrm{M}\right)$, as well as compound 7a for comparison, were tested for the inhibition against ALR1. All of the tested compounds were found to be slightly active with inhibition percentage in $100 \mu \mathrm{M}$, demonstrating their selectivity for ALR2. Compound 71 which exhibited strongest inhibition of ALR2 had an excellent selectivity with the selectivity index (SI) of 25.23, which was much higher than that of epalrestat.

\subsection{Antioxidant Activity}

\subsubsection{DPPH Radical Scavenging Activity}

Oxidative stress is one of crucial factors in the pathological processes of many disorders, including chronic diabetic complications. To retard the progression of oxidative stress and to ameliorate the disease, ARIs are expected to have significant antioxidant properties. Thus, the antioxidant capacities of the compounds which were effective in the ALR2 inhibition were estimated.

In this part, the antioxidant activity was measured by an intrinsic chemical reactivity toward radicals, in a homogeneous reaction system of the methanol solution of 1,1-diphenyl-2-trinitrophenylhydrazine (DPPH) $(0.2 \mathrm{mM})$, and 6-hydroxy-2,5,7,8-tetramethylchroman-2-carboxylic acid (Trolox) served as a reference compound. The derivatives 7c, $7 \mathrm{~g}$ and $7 \mathbf{k}-\mathbf{l}$ which already had exhibited good selectivity toward to ALR2 inhibition were tested for DPPH radical scavenging activity, as well as compound 7a serving as comparison. Interestingly, much superior to well-known antioxidant Trolox and reported deferiprone (3-hydroxy-1,2-dimethyl-1H-pyridin-4-one) [36], phenolic derivatives 7k-1 showed excellent DPPH radical scavenging ability, revealing that the phenolic substituents might be a key structure enhancing DPPH free radical scavenging activity (Table 2). Particularly, at a concentration of $1 \mu \mathrm{M}$, compound 71 had most favorable antioxidant properties, achieving $41.48 \%$ of inhibition rate. In addition, all the compounds without hydroxyl subunit at C2-styryl exhibited moderate antioxidant activity, proving that 5-hydroxy-2-styryl-1H-pyridin-4-ones were qualified antioxidants.

Table 2. DPPH radical scavenging activity of 5-hydroxy-4-oxo-2-styryl-4H-pyridinone derivatives.

\begin{tabular}{|c|c|c|c|c|c|}
\hline \multirow{2}{*}{ Comp. } & \multirow{2}{*}{$\mathbf{R}$} & \multicolumn{4}{|c|}{$\%$ of Inhibition of Control Value 1} \\
\hline & & $100 \mu \mathrm{M}$ & $10 \mu \mathbf{M}$ & $5 \mu \mathbf{M}$ & $1 \mu \mathrm{M}$ \\
\hline $7 a$ & $\mathrm{H}$ & $22.90 \pm 3.30$ & & & \\
\hline $7 \mathrm{c}$ & $p$-tBu & $25.44 \pm 2.36$ & & & \\
\hline $7 \mathrm{~g}$ & $m, \mathrm{p}-\mathrm{F} 2$ & $28.50 \pm 0.95$ & & & \\
\hline $7 \mathbf{k}$ & $p-\mathrm{OH}$ & $96.69 \pm 0.72$ & $89.31 \pm 0.62$ & $72.01 \pm 1.80$ & $33.08 \pm 0.72$ \\
\hline 71 & $m, \mathrm{p}-(\mathrm{OH}) 2$ & $97.96 \pm 0.36$ & $82.44 \pm 1.65$ & $67.18 \pm 0.62$ & $41.48 \pm 0.95$ \\
\hline \multicolumn{2}{|c|}{ Deferiprone $^{2}$} & 63 & & & \\
\hline \multicolumn{2}{|c|}{ Trolox } & $92.32 \pm 0.19$ & $80.33 \pm 1.22$ & $45.53 \pm 1.12$ & $11.89 \pm 1.39$ \\
\hline
\end{tabular}




\subsubsection{Lipid Peroxidation Suppression}

Lipid peroxidation reactions involve free radical attacks on unsaturated fatty acid, producing free radicals and lipid peroxides which eventually harm the organism and usually decompose to form poisonous malonaldehyde (MDA). Thiobarbituric acid reactive substances (TBARS), which generated from the condensation of thiobarbituric acid and malondialdehyde, are considered as key biomarkers to determine the level of lipid peroxidation. For further identification that the derivatives tested in DPPH scavenging assay can be effective in heterogeneous oxidative pathway, the suppression effect of compounds on the hydroxyl radical-dependent lipoperoxidation in rat brain homogenate oxidant system which induced by Fe(III)/ascorbic acid was also evaluated.

Compounds $7 \mathrm{a}, 7 \mathrm{c}, 7 \mathrm{~g}$ and $7 \mathrm{k}-1$ that were already described in the DPPH radical scavenging activity were investigated in the suppression of lipid peroxidation (Table 3). Consistent with results from the DPPH radical scavenging assay, the lipid peroxidation suppression showed that all tested compounds were active in the indicative heterogeneous assay, which was comparable to reported antioxidant deferiprone [37]. Remarkably, greater than the positive control Trolox and deferiprone, compounds $7 \mathbf{k}-\mathbf{l}$ showed an attractive activity inhibiting the production of MDA, further confirming that the hydroxyl styryl structures of (5-hydroxy-4-oxo-2-styryl-4H-pyridin-1-yl)-acetic acid derivatives were important in the antioxidant activity.

Table 3. Inhibition data of lipid peroxidation for 5-hydroxy-4-oxo-2-styryl-4H-pyridinone derivatives.

\begin{tabular}{|c|c|c|}
\hline Comp. & $\mathbf{R}$ & MDA inh. $\%^{1}$ \\
\hline $7 a$ & $\mathrm{H}$ & $19.28 \pm 0.98$ \\
\hline $7 c$ & $p$-tBu & $26.10 \pm 1.06$ \\
\hline $7 \mathrm{~g}$ & $m, p-\mathrm{F}_{2}$ & $55.02 \pm 3.00$ \\
\hline $7 \mathbf{k}$ & $p-\mathrm{OH}$ & $90.73 \pm 3.97$ \\
\hline 71 & $m, p-(\mathrm{OH})_{2}$ & $88.76 \pm 2.04$ \\
\hline Deferiprone ${ }^{2}$ & & 25 \\
\hline Trolox & & $74.82 \pm 1.82$ \\
\hline
\end{tabular}

Combined with the conclusions from both DPPH radical scavenging assay and the lipid peroxidation suppression experiment, 5-hydroxy-4-oxo-2-styryl-4H-pyridine derivatives have been proved their good antioxidant capacity. Compared favorably with Trolox, the typical antioxidant agent, hydroxystyryl derivatives provided excellent anti-oxidative activity, revealing that the hydroxyl groups in C2- styryl side chain were critical structures behaving like the ideal antioxidant.

\subsection{Molecular Docking}

To propose the binding mode of 5-hydroxy-4-oxo-2-styryl-4H-pyridine derivatives at a molecular level and to further illustrate the relationship between structure and ALR2 inhibitory activity, molecular docking assays of compounds which endowed with good activity in the ALR2 inhibition were performed by software Molegro Virtual Docker, version 6.0. As shown in Figure 2, compounds 7c, $\mathbf{7 d}, 7 \mathrm{~g}$ and $\mathbf{7 k}-\mathbf{l}$, as well as compound $\mathbf{7 a}$ and $\mathbf{7 i}$ which set as comparison, were docked well into the active site of the human ALR2/NADP+/lidorestat complex (PDB code: 1Z3N) [38]. By strong hydrogen bonds interaction and pi-pi stacking with the side chain of the residues, the carboxyl groups of these compounds were deeply inserted into the anion binding pocket consisted by His 110, Trp 111, Tyr 48, Val 47, Trp 20 and cofactor NADPH. However, the carboxyl group of compound 7i partially "flowed 
out" of the anion binding pocket, confirming that 7i was inactive in inhibiting ALR2, according to the minimum requirement of a qualified inhibitor posed by Costantino et al. [39]. Interestingly, hydrogen bonds were created between the carboxylic groups and His110/Trp 111 residues, as well as between hydroxyl groups in pyridinone core and Val 47/Trp 20 residues, which lying opposite side of His 110 and Trp 111 residues in this pocket. Thus, it is suggested that these carboxylic pyridinones might readily and totally blockade the activate site catalyzing the reduction of aldose. Notably, an additional hydrogen bond was formed vigorously between the hydroxyl group in C2-styryl side chain of 71 and residue Thr 103 which located in specificity pocket, letting the specificity pocket be closed, which is in line with the recently published docking result of potent inhibitors, cemtirestat O-analog [23]. Thus, it was proved that 71 was much more active than the others.
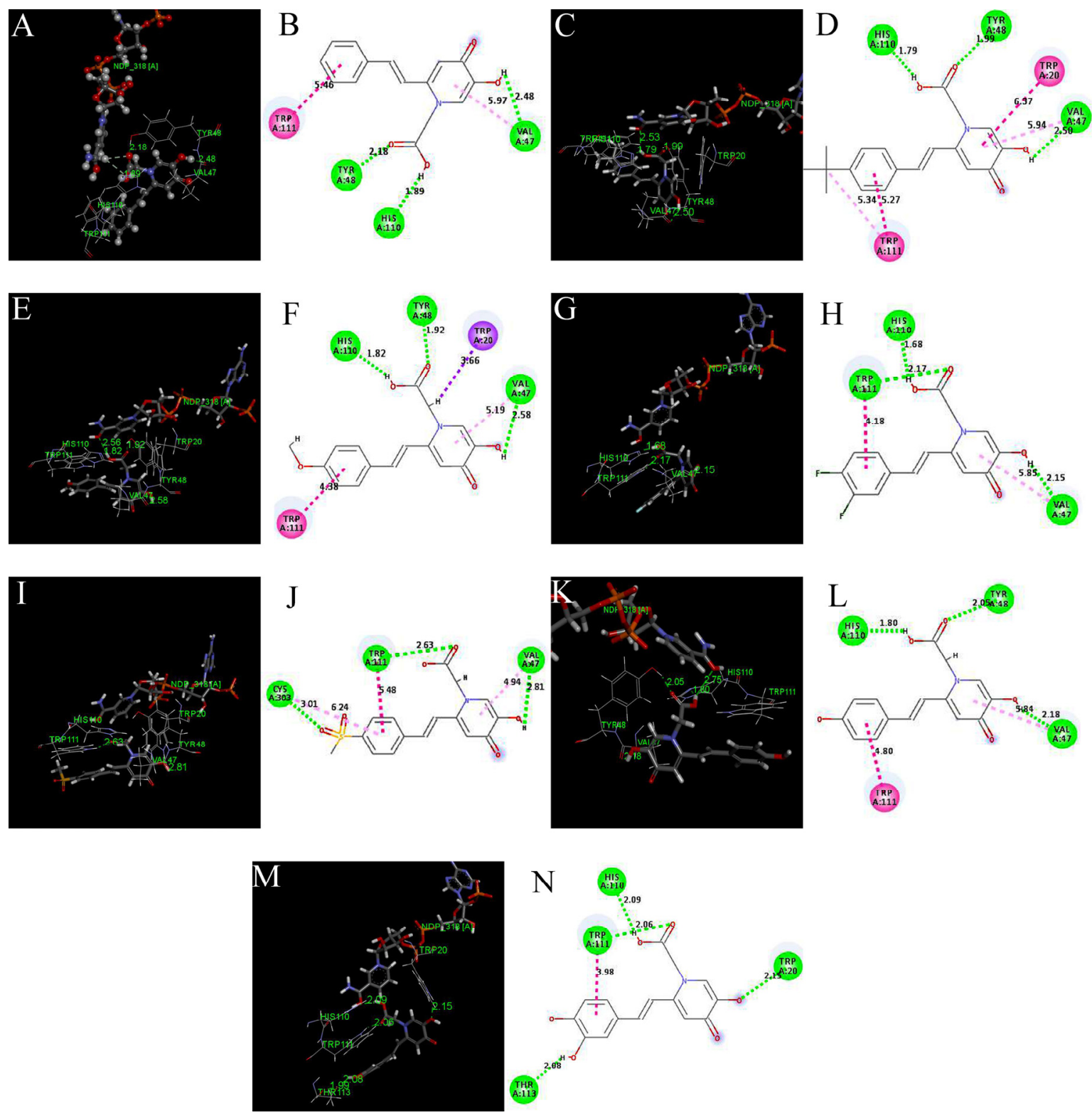

Figure 2. 3D docking results and $2 \mathrm{D}$ visualization of 5-hydroxy-4-oxo-2-styryl-4H-pyridine derivatives 7a (A and B), 7c (C and D), 7d (E and F), 7g (G and H), 7i (I and J), 7k (K and $\mathbf{L})$ and $7 \mathbf{l}(\mathbf{M}$ and $\mathbf{N})$, respectively. In $3 \mathrm{D}$ docking results, the docked poses of the compounds are shown in gray $(\mathbf{C})$, red $(\mathbf{O})$, white $(\mathbf{H})$ and blue $(\mathbf{N})$, and hydrogen bonds are shown as yellow dashed lines, and lengths $(\AA)$ of the hydrogen bonds are labeled beside the dashed lines. In 2D representation, hydrogen bonds are shown as green dashed lines, and pi-pi stacking as pink dashed lines. 
To further understand the inhibitory action of 5-hydroxy-4-oxo-2-styryl-4H-pyridine derivatives in detail, the binding energy and inhibitory constant $(\mathrm{Ki})$ for $\mathbf{7 a}, \mathbf{7 c}, \mathbf{7 d}, \mathbf{7 g}$ and $\mathbf{7 k}-\mathbf{1}$ were calculated (Table 4). Since poor interaction with enzyme complex, data of $\mathbf{7 i}$ was out of consideration. In general, ranging from 2.06 to $3.23 \mu \mathrm{M}$, the predicted $\mathrm{Ki}$ data of all compounds were closely related to the $\mathrm{IC}_{50}$ values, verifying the ALR2 inhibitory actions of the derivatives. Significantly, lower Ki for $\mathbf{7 c}, \mathbf{7 d}, \mathbf{7 g}$ and $7 \mathbf{k}-\mathbf{1}$ were found rather than that for $\mathbf{7 a}$, demonstrating better ALR2 affinities of the derivatives substituted with electronic-donating groups or the alkyl groups at C2-styryl side chains. This result was entirely consistent with the result from ALR2 inhibitory assay, of which the $\mathrm{IC}_{50}$ data of $7 \mathrm{c}, \mathbf{7 d}$, $7 \mathbf{g}$ and $7 \mathbf{k}-\mathbf{1}$ were lower than that of $\mathbf{7 a}$. Notably, among all of these compounds, $7 \mathbf{l}$, which acquired most favorable $\mathrm{IC}_{50} 0.789 \mu \mathrm{M}$, had the minimum value of $\mathrm{Ki} 2.06 \mu \mathrm{M}$, illustrating that phenolic 71 was prominently potent when binding into the ALR2 active site. Tightly interacting with anion binding site and provided with lowest value of $\mathrm{Ki}$, phenolic 71 thus had the most desirable binding affinity, along with the pattern of ALR2 inhibition.

Table 4. Docking scores for 5-hydroxy-4-oxo-2-styryl-4H-pyridine compounds binding ALR2 and ALR1.

\begin{tabular}{|c|c|c|c|c|c|}
\hline \multirow[b]{2}{*}{ Comp. } & \multirow[b]{2}{*}{$\mathbf{R}$} & \multicolumn{3}{|c|}{ ALR2 } & \multirow{2}{*}{$\begin{array}{c}\text { ALR1 } \\
\begin{array}{c}\text { Rerank Score } \\
\text { (kcal/mol) }\end{array}\end{array}$} \\
\hline & & $\begin{array}{l}\text { Rerank Score } \\
\text { (kcal/mol) }\end{array}$ & $\begin{array}{c}\mathrm{E}_{\text {binding }} \\
\text { (kcal/mol) }\end{array}$ & $\begin{array}{c}\mathbf{K i} \\
(\mu \mathrm{M})\end{array}$ & \\
\hline $7 a$ & $\mathrm{H}$ & -96.068 & -7.49 & 3.23 & -96.381 \\
\hline $7 \mathrm{c}$ & $p$-tBu & -108.806 & -7.55 & 2.93 & -103.082 \\
\hline $7 d$ & $p$-OMe & -106.12 & -7.55 & 2.92 & \\
\hline $7 g$ & $m, p-\mathrm{F}_{2}$ & -112.514 & -7.54 & 2.98 & \\
\hline $7 \mathbf{k}$ & $p-\mathrm{OH}$ & -112.86 & -7.63 & 2.54 & -97.062 \\
\hline 71 & $m, p-(\mathrm{OH})_{2}$ & -115.158 & -7.76 & 2.06 & -90.375 \\
\hline
\end{tabular}

To investigate the selectiveness towards ALR2 over ALR1, the binding behaviors of derivatives with the ALR1-NADP+ complex (PDB code: 1ZUA) [40] were also discussed. The binding energies of compounds $\mathbf{7 a}, \mathbf{7 c}$ and $\mathbf{7 k}-\mathbf{1}$ were calculated and displayed in Table 4. Remarkably, in agreement with the results in the inhibition experiment against ALR1, these data were explicit that 71 exhibited a higher reranked score than $\mathbf{7 a}$ did, proving that this phenolic compound acquired good selectivity for ALR2.

\section{Materials and Methods}

\subsection{General}

Melting points were recorded on an X-4 microscopic melting point apparatus (Shanghai Jingke Instrument Co., Ltd, Shanghai, China) and are uncorrected. All reactions were routinely checked by TLC on silica gel Merck 60F254. The NMR spectra were recorded on a Bruker Ascend $400 \mathrm{M}$ spectrometer (400 MHz for ${ }^{1} \mathrm{H} \mathrm{NMR}, 100 \mathrm{MHz}$ for ${ }^{13} \mathrm{C}$ NMR, Bruker Corporation, Billerica, MA, USA) and chemical shifts were given in $\delta$ units (ppm) relative to internal standard TMS and refer to DMSO-d6 solutions. HRMS (ESI) was performed using an AGILENT LC/MS (Agilent Technologies Inc., Palo Alto, CA, USA). Analysis of sample purity was performed on a Hitachi D-2000 Elite HPLC system (Hitachi, Ltd., Tokyo, Japan). HPLC conditions were the following: Inertsil ODS-2 $250 \mathrm{~mm} \times 10 \mathrm{~mm}$, $5 \mathrm{~mm}$ column; mobile phase: $\mathrm{CH}_{3} \mathrm{CN}(0.1 \% \mathrm{TFA}) / \mathrm{CH}_{3} \mathrm{OH}=1 / 1$, for $10 \mathrm{~min}$; room temperature;

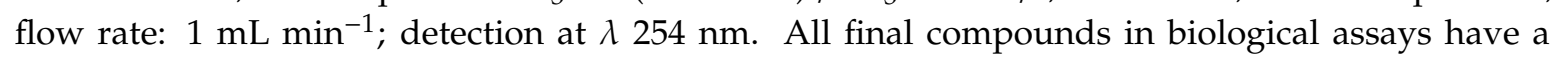
purity of $\geq 95 \%$. 


\subsection{Synthetic Procedures Preparing Title Compounds}

Preparation of compounds 2-4 was reported previously [34]. With partial modification, the procedures for preparing title compounds are as followed.

\subsubsection{Synthetic Procedure for 5-benzyloxy-2-hydroxymethyl-pyran-4-one (2)}

To a solution of kojic acid (1) $(28.4 \mathrm{~g}, 0.2 \mathrm{~mol})$ in isopropanol $(200 \mathrm{~mL})$ sodium hydroxide $(8.8 \mathrm{~g}$, $0.2 \mathrm{~mol})$ aqueous solution $(20 \mathrm{~mL})$ was added, and the mixture was heated to reflux. Benzyl chloride (28 $\mathrm{g}, 0.2 \mathrm{~mol}$ ) was added dropwise into the mixture over $30 \mathrm{~min}$, and the resulting mixture was refluxed for $4 \mathrm{~h}$. After removal of the solvent by rotary evaporation, the brown solid was washed with water $(80 \mathrm{~mL})$ followed by acetate ester $(200 \mathrm{~mL})$ then recrystallized from ethanol to give the pure product $(32.28 \mathrm{~g}, 69.6 \%) .{ }^{1} \mathrm{H}$ NMR $(400 \mathrm{MHz}, \mathrm{DMSO}) \delta 7.91(\mathrm{~s}, 1 \mathrm{H}), 7.19(\mathrm{~m}, 5 \mathrm{H}), 6.17(\mathrm{~s}, 1 \mathrm{H})$, $4.81(\mathrm{~s}, 2 \mathrm{H}), 4.14(\mathrm{~s}, 2 \mathrm{H})$.

\subsubsection{Synthetic Procedure for 5-benzyloxy-2-chloromethyl-pyran-4-one (3)}

$2(46.4 \mathrm{~g}, 0.2 \mathrm{~mol})$ was added in flask containing $300 \mathrm{~mL}$ dichloromethane, $22 \mathrm{~mL}$ thionyl chloride was added dropwise at $0^{\circ} \mathrm{C}$. The reaction mixture was stirred at room temperature for $2 \mathrm{~h}$. After filtration, the solid was washed with petroleum $200 \mathrm{~mL}$ to get white solid (55.66 g, 74\%). ${ }^{1} \mathrm{H} \mathrm{NMR}$ (400 MHz, DMSO) $\delta 7.53$ (s, 1H), 7.32 (m, 5H), 6.35 (s, 1H), 5.16 (s, 2H), 4.22 (s, 2H).

3.2.3. Synthetic Procedure for ((5-(benzyloxy)-4-oxo-4H-pyran-2-yl)methyl)triphenylphosphonium chloride (4)

$3(25 \mathrm{~g}, 0.1 \mathrm{~mol})$ was dissolved in dried tetrahydrofuran $(100 \mathrm{~mL})$, triphenylphosphine $(26.2 \mathrm{~g}$, $0.1 \mathrm{~mol}$ ) was added, and the mixture was refluxed overnight. The solvent was then evaporated, and the residue washed with ethyl acetate to get the solid $(22.12 \mathrm{~g}, 43.2 \%)$.

\subsubsection{General Procedure Preparing 5-benzyloxy-2-styryl-pyran-4-one (5)}

Into the mixture of $4(5.13 \mathrm{~g}, 10 \mathrm{mmol})$ and benzaldehyde $(11 \mathrm{mmol})$ in dichloromethane $(20 \mathrm{~mL})$, aqueous solution of sodium hydroxide $(50 \%, 6 \mathrm{~mL})$ was dropwise added over $15 \mathrm{~min}$, and the mixture was stirred at room temperature for $2 \mathrm{~h}$. Water was added and the resulting solution was extracted with dichloromethane $(50 \mathrm{~mL} \times 3)$. The combined organic layers were gathered and concentrated in vacuo, and the residue was then recrystallized from ethanol to get a white or yellow solid (25 87\%).

5-Benzyloxy-2-styryl-pyran-4-one (5a) (78\%). ${ }^{1} \mathrm{H}$ NMR (400 $\left.\mathrm{MHz} \mathrm{CDCl}_{3}\right) \delta 7.55$ (s, $\left.1 \mathrm{H}\right), 7.49$ $(\mathrm{d}, J=7.1 \mathrm{~Hz}, 2 \mathrm{H}), 7.31(\mathrm{~m}, 9 \mathrm{H}), 6.63(\mathrm{~d}, J=16.1 \mathrm{~Hz}, 1 \mathrm{H}), 6.39(\mathrm{~s}, 1 \mathrm{H}), 5.11(\mathrm{~s}, 2 \mathrm{H}) .{ }^{13} \mathrm{C} \mathrm{NMR}$ (100 MHz, d6-DMSO) $\delta 174.41,161.44,146.37,139.61,137.02,135.46,135.28,130.04,129.41,128.42$, $128.37,128.34,128.00,120.63,112.58,59.50$.

5-Benzyloxy-2-(2-p-tolyl-vinyl)-pyran-4-one (5b) (71\%). ${ }^{1} \mathrm{H} \mathrm{NMR}\left(400 \mathrm{MHz}, \mathrm{CDCl}_{3}\right) \delta 7.58(\mathrm{~s}, 1 \mathrm{H}), 7.67(\mathrm{~d}$, $J=7.2 \mathrm{~Hz}, 2 \mathrm{H}), 7.30(\mathrm{~m}, 8 \mathrm{H}), 6.54(\mathrm{~d}, J=16.0 \mathrm{~Hz}, 1 \mathrm{H}), 6.30(\mathrm{~s}, 1 \mathrm{H}), 5.13(\mathrm{~s}, 2 \mathrm{H}), 2.32(\mathrm{~s}, 3 \mathrm{H}) .{ }^{13} \mathrm{C} \mathrm{NMR}$ (100 MHz, d6-DMSO) $\delta$ 174.93, 161.25, 146.21, 139.17, 137.64, 135.77, 135.79, 129.64, 129.51, 128.65, $128.38128 .31,128.12120 .79,112.45,58.41,21.47$.

5-Benzyloxy-2-[2-(4-tert-butyl-phenyl)-vinyl]-pyran-4-one (5c) (46\%). ${ }^{1} \mathrm{H} \mathrm{NMR}\left(400 \mathrm{MHz}, \mathrm{CDCl}_{3}\right) \delta 7.55$ (s, $1 \mathrm{H}), 7.60(\mathrm{~d}, J=7.2 \mathrm{~Hz}, 2 \mathrm{H}), 7.32(\mathrm{~m}, 8 \mathrm{H}), 6.61(\mathrm{~d}, J=16.0 \mathrm{~Hz}, 1 \mathrm{H}), 6.44(\mathrm{~s}, 1 \mathrm{H}), 5.15(\mathrm{~s}, 2 \mathrm{H}), 1.41(\mathrm{~s}, 9 \mathrm{H})$. ${ }^{13} \mathrm{C}$ NMR (100 MHz, d6-DMSO) $\delta 174.35,161.63,146.01,139.91,137.87,135.45,134.91,129.98,128.79$, $128.88,128.36,128.33,127.83,120.12,112.27,56.84,34.95,31.45$.

5-Benzyloxy-2-[2-(4-methoxy-phenyl)-vinyl]-pyran-4-one (5d) (44\%). ${ }^{1} \mathrm{H}$ NMR (400 $\left.\mathrm{MHz}, \mathrm{CDCl}_{3}\right)$ $\delta 7.53(\mathrm{~s}, 1 \mathrm{H}), 7.38(\mathrm{~m}, 7 \mathrm{H}), 7.27(\mathrm{~d}, J=16.0 \mathrm{~Hz}, 1 \mathrm{H}), 6.91(\mathrm{~m}, 2 \mathrm{H}), 6.50(\mathrm{~d}, J=16.0 \mathrm{~Hz}, 1 \mathrm{H}), 6.37(\mathrm{~s}, 1 \mathrm{H})$, 5.12 (s, 2H), 3.89 (s, 3H). ${ }^{13} \mathrm{C}$ NMR (100 MHz, d6-DMSO) $\delta 173.01,160.88,146.18,139.27,136.94,136.03$, $135.88,135.41,130.14,128.43,128.39,128.21,127.12,127.03,113.80,74.32,56.55$. 
5-Benzyloxy-2-[2-(3,4-dimethoxy-phenyl)-vinyl]-pyran-4-one (5e) (48\%). ${ }^{1} \mathrm{H} \mathrm{NMR}\left(400 \mathrm{MHz}, \mathrm{CDCl}_{3}\right) \delta 7.55$ $(\mathrm{s}, 1 \mathrm{H}), 7.36(\mathrm{~m}, 5 \mathrm{H}), 7.28(\mathrm{~d}, J=4.7 \mathrm{~Hz}, 1 \mathrm{H}), 6.64(\mathrm{~m}, 3 \mathrm{H}), 6.48(\mathrm{t}, J=2.5 \mathrm{~Hz}, 1 \mathrm{H}), 6.36(\mathrm{~s}, 1 \mathrm{H}), 5.12(\mathrm{~s}$, 2H), 3.83 (s, 6H). ${ }^{13} \mathrm{C}$ NMR (100 MHz, d6-DMSO) $\delta 174.40,161.22,147.51,139.49,137.57,137.01,135.28$, $129.41,128.42,128.37,127.31,121.48,120.63,112.58,106.34,102.05,59.33$.

5-Benzyloxy-2-[2-(4-fluoro-phenyl)-vinyl]-pyran-4-one (5f) (56\%). ${ }^{1} \mathrm{H}$ NMR (400 $\mathrm{MHz}, \mathrm{CDCl}_{3}$ ) $\delta 7.55(\mathrm{~s}, 1 \mathrm{H}), 7.30(\mathrm{~m}, 8 \mathrm{H}), 7.21(\mathrm{~d}, J=9.7 \mathrm{~Hz}, 1 \mathrm{H}), 7.11(\mathrm{dd}, J=8.2,2.4 \mathrm{~Hz}, 1 \mathrm{H}), 6.63(\mathrm{~d}, J=$ $16.1 \mathrm{~Hz}, 1 \mathrm{H}), 6.41(\mathrm{~s}, 1 \mathrm{H}), 5.12(\mathrm{~s}, 2 \mathrm{H}) .{ }^{13} \mathrm{C}$ NMR $(100 \mathrm{MHz}, d 6-\mathrm{DMSO}) \delta 174.42,163.09,161.36,146.58$, $139.52,137.49,136.03,133.88,131.41,128.39,128.21,127.12,124.46,122.16,116.59,114.07,112.91,57.41$.

5-Benzyloxy-2-[2-(3,4-difluoro-phenyl)-vinyl]-pyran-4-one (5g) (63\%). ${ }^{1} \mathrm{H} \mathrm{NMR}\left(400 \mathrm{MHz}, \mathrm{CDCl}_{3}\right) \delta 7.55$ (s, $1 \mathrm{H}), 7.21(\mathrm{~m}, 10 \mathrm{H}), 6.64(\mathrm{~d}, J=16.1 \mathrm{~Hz}, 1 \mathrm{H}), 6.39(\mathrm{~s}, 1 \mathrm{H}), 5.10(\mathrm{~s}, 2 \mathrm{H}) .{ }^{13} \mathrm{C}$ NMR $(100 \mathrm{MHz}, d 6-\mathrm{DMSO}) \delta$ $176.12,162.77,146.92,144.28,135.46,130.69,128.42,128.37,128.34,125.38,123.68,120.79,111.07,108.86$, $104.18,59.74$.

5-Benzyloxy-2-[2-(4-trifluoromethyl-phenyl)-vinyl]-pyran-4-one (5h) (66\%). ${ }^{1} \mathrm{H}$ NMR $\left(400 \mathrm{MHz}, \mathrm{CDCl}_{3}\right) \delta$ $7.55(\mathrm{~s}, 1 \mathrm{H}), 7.28(\mathrm{~m}, 8 \mathrm{H}), 7.26(\mathrm{~d}, J=9.3 \mathrm{~Hz}, 1 \mathrm{H}), 7.08(\mathrm{dd}, J=8.4,2.1 \mathrm{~Hz}, 1 \mathrm{H}), 6.60(\mathrm{~d}, J=16.1 \mathrm{~Hz}, 1 \mathrm{H})$, $6.46(\mathrm{~s}, 1 \mathrm{H}), 5.15$ (s, 2H). ${ }^{13} \mathrm{C}$ NMR $(100 \mathrm{MHz}, d 6$-DMSO) $\delta 174.59,160.28,156.79,146.82,141.76,139.23$, $135.28,132.84,129.05,128.63,128.42,128.37,128.34,124.60,120.83,113.28,59.50$.

5-Benzyloxy-2-[2-(4-methanesulfonyl-phenyl)-vinyl]-pyran-4-one (5i) $(78 \%) .{ }^{1} \mathrm{H}$ NMR $\left(400 \mathrm{MHz}, \mathrm{CDCl}_{3}\right) \delta$ $7.55(\mathrm{~s}, 1 \mathrm{H}), 7.31(\mathrm{~m}, 8 \mathrm{H}), 7.20(\mathrm{~d}, J=9.5 \mathrm{~Hz}, 1 \mathrm{H}), 7.11(\mathrm{dd}, J=8.0,2.5 \mathrm{~Hz}, 1 \mathrm{H}), 6.83(\mathrm{~d}, J=16.1 \mathrm{~Hz}, 1 \mathrm{H})$, 6.55 (s, 1H), 5.15 (s, 2H), 3.30 (s, 3H). ${ }^{13} \mathrm{C}$ NMR (100 MHz, d6-DMSO) $\delta 173.03,164.63,149.25,143.46$, $137.77,136.92,134.94,128.82,128.73,128.18$ 127.65, 127.25, 122.72, 120.63, 111.74, 58.32, 41.62.

$\mathrm{N}$-\{4-[2-(5-Benzyloxy-4-oxo-4H-pyran-2-yl)-vinyl]-phenyl\}-acetamide (5j) (25\%). ${ }^{1} \mathrm{H}$ NMR $(400 \mathrm{MHz}$, $\left.\mathrm{CDCl}_{3}\right) \delta 10.23(\mathrm{~s}, 1 \mathrm{H}), 8.22(\mathrm{~s}, 1 \mathrm{H}), 7.63(\mathrm{~m}, 4 \mathrm{H}), 7.40(\mathrm{~d}, \mathrm{~J}=2.6 \mathrm{~Hz}, 2 \mathrm{H}), 7.14(\mathrm{~m}, 4 \mathrm{H}), 5.14(\mathrm{~s}, 2 \mathrm{H})$, $2.10(\mathrm{~s}, 3 \mathrm{H}) .{ }^{13} \mathrm{C}$ NMR $(100 \mathrm{MHz}, d 6-\mathrm{DMSO}) \delta 174.41,171.29,162.64,151.69,146.10$ 139.04, 137.02, $136.08,131.49,129.88,129.57,128.42,128.37,128.34,128.00,112.58,110.29,59.50,24.51$.

\subsubsection{General Procedure Preparing (5-Benzyloxy-4-oxo-2-styryl-4H-pyridin-1-yl)-acetic Acid (6)}

5 ( $3 \mathrm{mmol})$ dissolved in isopropanol $(5 \mathrm{~mL})$ and the mixture was added into glycine $(20 \mathrm{mmol})$ aqueous solution $15 \mathrm{~mL}$, then followed by aqueous solution of sodium hydroxide $(50 \%, 6 \mathrm{~mL})$ added into the mixture to ensure the $\mathrm{pH}$ value maintain $8 \sim 9$. The resulting suspension was refluxed for $16 \sim 36 \mathrm{~h}$, till the mixture presented as clear solution. After evaporation to remove solvent isopropanol, $8 \mathrm{M} \mathrm{HCl}$ solution was added to adjust the $\mathrm{pH}$ to 2 . A precipitate was obtained and filtered, and then washed by water to get white or yellow solid. (12 27\%)

(5-Benzyloxy-4-oxo-2-styryl-4H-pyridin-1-yl)-acetic acid (6a) (22\%). ${ }^{1} \mathrm{H}$ NMR (400 MHz, d6-DMSO) $\delta 7.58(\mathrm{~m}, 2 \mathrm{H}), 7.51-7.19(\mathrm{~m}, 10 \mathrm{H}), 7.01(\mathrm{~m}, 2 \mathrm{H}), 5.49(\mathrm{~s}, 2 \mathrm{H}), 5.02(\mathrm{~s}, 2 \mathrm{H}) .{ }^{13} \mathrm{C}$ NMR $(100 \mathrm{MHz}$, d6-DMSO) $\delta 169.31,163.24,160.83,147.66,139.92,137.43,135.94,135.26,131.82,129.92,128.46,128.34$, $128.28,128.11,121.87,111.72,59.94,56.31$.

[5-Benzyloxy-4-oxo-2-(2-p-tolyl-vinyl)-4H-pyridin-1-yl]-acetic acid (6b) (25\%). ${ }^{1} \mathrm{H}$ NMR $(400 \mathrm{MHz}$, $d 6-\mathrm{DMSO}) \delta 7.57(\mathrm{~m}, 2 \mathrm{H}), 7.57-7.22(\mathrm{~m}, 10 \mathrm{H}), 7.06(\mathrm{~m}, 2 \mathrm{H}), 5.44(\mathrm{~s}, 2 \mathrm{H}), 5.01(\mathrm{~s}, 2 \mathrm{H}), 2.33(\mathrm{~s}, 3 \mathrm{H})$. ${ }^{13} \mathrm{C}$ NMR (100 MHz, d6-DMSO) $\delta 169.27,162.24,161.23,146.64,140.37,137.13,136.01,135.21,129.84$, $129.42,128.79,128.48$ 128.33, 128.06, 122.43, 115.56, 58.84, 56.17, 22.42.

\{5-Benzyloxy-2-[2-(4-tert-butyl-phenyl)-vinyl]-4-oxo-4H-pyridin-1-yl\}-acetic acid (6c) (14\%). ${ }^{1} \mathrm{H}$ NMR (400 MHz, d6-DMSO) $\delta 7.58(\mathrm{~m}, 2 \mathrm{H}), 7.52-7.13(\mathrm{~m}, 10 \mathrm{H}), 6.98(\mathrm{~m}, 2 \mathrm{H}), 5.40(\mathrm{~s}, 2 \mathrm{H}), 5.06(\mathrm{~s}, 2 \mathrm{H}), 1.31(\mathrm{~s}, 9 \mathrm{H})$. ${ }^{13} \mathrm{C}$ NMR (100 MHz, d6-DMSO) $\delta 168.94,163.60,161.92,145.91,140.38,136.87,135.28,135.41,130.24$, $129.33,128.65,128.42,128.28,127.66,120.01,114.68,59.71,55.91,34.03,30.33$.

\{5-Benzyloxy-2-[2-(4-methoxy-phenyl)-vinyl]-4-oxo-4H-pyridin-1-yl\}-acetic acid (6d) (25\%). ${ }^{1} \mathrm{H}$ NMR (400 MHz, d6-DMSO) $\delta 7.62(\mathrm{~s}, 1 \mathrm{H}), 7.33(\mathrm{~m}, 12 \mathrm{H}), 5.32(\mathrm{~s}, 2 \mathrm{H}), 5.01(\mathrm{~s}, 2 \mathrm{H}), 3.86(\mathrm{~s}, 3 \mathrm{H}) .{ }^{13} \mathrm{C} \mathrm{NMR}(100 \mathrm{MHz}$, 
d6-DMSO) $\delta 168.85,161.41,160.23,147.31,138.61,137.45,136.00,135.71,135.22,129.63,128.84,128.71$, $128.62,127.51,127.39,115.06,78.04,56.92,54.17$

\{5-Benzyloxy-2-[2-(3,4-dimethoxy-phenyl)-vinyl]-4-oxo-4H-pyridin-1-yl\}-acetic acid (6e) (13\%). ${ }^{1} \mathrm{H}$ NMR $(400 \mathrm{MHz}, d 6-\mathrm{DMSO}) \delta 7.77(\mathrm{~s}, 1 \mathrm{H}), 7.38(\mathrm{~m}, 7 \mathrm{H}), 7.06(\mathrm{~d}, J=16.2 \mathrm{~Hz}, 1 \mathrm{H}), 6.75(\mathrm{~d}, J=2.0 \mathrm{~Hz}, 2 \mathrm{H})$, $6.47(\mathrm{~s}, 1 \mathrm{H}), 5.30(\mathrm{~s}, 2 \mathrm{H}), 5.11(\mathrm{~s}, 2 \mathrm{H}), 3.78(\mathrm{~s}, 6 \mathrm{H}) .{ }^{13} \mathrm{C}$ NMR $(100 \mathrm{MHz}, d 6-\mathrm{DMSO}) \delta$ 169.04, 160.19, $159.41,148.86,140.83,138.76,136.69,135.92,130.53,129.10,128.91,127.58,122.33,121.20,113.44,107.08$, $101.45,57.26,55.23$.

\{5-Benzyloxy-2-[2-(4-fluoro-phenyl)-vinyl]-4-oxo-4H-pyridin-1-yl\}-acetic acid (6f) (25\%). ${ }^{1} \mathrm{H}$ NMR (400 MHz, d6-DMSO) $\delta 7.80(\mathrm{~m}, 12 \mathrm{H}), 7.12(\mathrm{~s}, 1 \mathrm{H}), 5.28(\mathrm{~s}, 2 \mathrm{H}), 5.20(\mathrm{~s}, 2 \mathrm{H}) .{ }^{13} \mathrm{C} \mathrm{NMR}(100 \mathrm{MHz}, d 6-\mathrm{DMSO}) \delta$ $169.18,161.92,161.64,160.22,140.43,138.96,137.31,137.11,132.93,132.07,129.22,128.78,127.99,125.84$, $122.18,117.24,113.63,110.42,59.68,57.24$.

\{5-Benzyloxy-2-[2-(3,4-difluoro-phenyl)-vinyl]-4-oxo-4H-pyridin-1-yl\}-acetic acid (6g) (20\%). ${ }^{1} \mathrm{H}$ NMR $(400 \mathrm{MHz}, d 6-\mathrm{DMSO}) \delta 7.42(\mathrm{~s}, 1 \mathrm{H}), 7.36(\mathrm{~m}, 5 \mathrm{H}), 7.30(\mathrm{~s}, 1 \mathrm{H}), 7.20(\mathrm{~m}, 2 \mathrm{H}), 6.96(\mathrm{~s}, 1 \mathrm{H})$, $6.83(\mathrm{~d}, J=16.1 \mathrm{~Hz}, 1 \mathrm{H}), 6.70(\mathrm{~s}, 1 \mathrm{H}), 5.33(\mathrm{~s}, 2 \mathrm{H}), 5.12(\mathrm{~s}, 2 \mathrm{H}) .{ }^{13} \mathrm{C}$ NMR (100 MHz, d6-DMSO) $\delta 169.84,160.63,159.28,147.05,145.20,135.83,131.04,129.74,128.84,128.34,126.97,123.41,121.04$, $110.26,107.43,101.87,58.22,56.81$.

\{5-Benzyloxy-4-oxo-2-[2-(4-trifluoromethyl-phenyl)-vinyl]-4H-pyridin-1-yl\}-acetic acid (6h) (18\%). ${ }^{1} \mathrm{H} \mathrm{NMR}$ $(400 \mathrm{MHz}, d 6-\mathrm{DMSO}) \delta 8.24(\mathrm{~d}, J=8.7 \mathrm{~Hz}, 2 \mathrm{H}), 7.86(\mathrm{~d}, J=8.7 \mathrm{~Hz}, 2 \mathrm{H}), 7.52(\mathrm{~d}, J=7.1 \mathrm{~Hz}, 1 \mathrm{H}), 7.47(\mathrm{~d}$, $J=7.3 \mathrm{~Hz}, 2 \mathrm{H}), 7.40(\mathrm{~m}, 3 \mathrm{H}), 7.34(\mathrm{~m}, 2 \mathrm{H}), 6.88(\mathrm{~s}, 1 \mathrm{H}), 5.21(\mathrm{~s}, 2 \mathrm{H}), 5.16(\mathrm{~s}, 2 \mathrm{H}) .{ }^{13} \mathrm{C} \mathrm{NMR}(100 \mathrm{MHz}$, d6-DMSO) $\delta 169.22,160.83,159.12,155.67,147.28,140.66,139.49,136.02,132.91,128.97,128.52,128.32$, $128.28,127.33,125.32,121.70,112.76,59.84,55.82$.

\{5-Benzyloxy-2-[2-(4-methanesulfonyl-phenyl)-vinyl]-4-oxo-4H-pyridin-1-yl\}-acetic acid (6i) (27\%). ${ }^{1} \mathrm{H}$ NMR $(400 \mathrm{MHz}, d 6-\mathrm{DMSO}) \delta 8.20(\mathrm{~d}, J=8.5 \mathrm{~Hz}, 2 \mathrm{H}), 7.88(\mathrm{~d}, J=8.3 \mathrm{~Hz}, 2 \mathrm{H}), 7.45(\mathrm{~d}, J=7.6 \mathrm{~Hz}, 1 \mathrm{H}), 7.33(\mathrm{~d}$, $J=7.1 \mathrm{~Hz}, 2 \mathrm{H}), 7.28(\mathrm{~m}, 3 \mathrm{H}), 7.13(\mathrm{~m}, 2 \mathrm{H}), 6.92(\mathrm{~s}, 1 \mathrm{H}), 5.17(\mathrm{~s}, 2 \mathrm{H}), 5.05(\mathrm{~s}, 2 \mathrm{H}) .{ }^{13} \mathrm{C} \mathrm{NMR}(100 \mathrm{MHz}$, $d 6$-DMSO) $\delta 169.63,161.08,159.81,148.74,144.40,137.26,136.48,130.26,129.42,128.68,128.55$ 127.71, $127.04,123.58,121.02,111.98,58.77,56.11,41.62$.

\{2-[2-(4-Acetylamino-phenyl)-vinyl]-5-benzyloxy-4-oxo-4H-pyridin-1-yl\}-acetic acid (6j) (12\%). ${ }^{1} \mathrm{H} \mathrm{NMR}$ $(400 \mathrm{MHz}, d 6-\mathrm{DMSO}) \delta 10.21(\mathrm{~s}, 1 \mathrm{H}), 8.26(\mathrm{~s}, 1 \mathrm{H}), 7.66(\mathrm{~m}, 4 \mathrm{H}), 7.43(\mathrm{~d}, J=2.6 \mathrm{~Hz}, 2 \mathrm{H}), 7.19(\mathrm{~m}, 4 \mathrm{H})$, 5.29 (s, 2H), 5.12 (s, 2H), 2.08 (s, 3H). ${ }^{13} \mathrm{C}$ NMR (100 MHz, d6-DMSO) $\delta 169.59,161.28,160.02,158.32$, 154.32, 147.48 138.62, 137.88, 136.01, 131.26, 129.54, 129.21, 128.44, 128.40, 128.21, 128.13, 113.63, 111.74, $59.50,56.65,24.51$.

\subsubsection{General Procedure Preparing (5-hydroxy-4-oxo-2-styryl-4H-pyridin-1-yl)-acetic Acid (7a-1)}

Method A: 6 ( $2 \mathrm{mmol})$ was dissolved in hydrochloric acid $(6 \mathrm{~N}, 10 \mathrm{~mL})$. The mixture was refluxed for $24 \mathrm{~h}$, resulting solid was filtered and recrystallized from ethanol to yield compounds $7 \mathrm{a}-\mathbf{i}$ with white to yellow solid. (71 88\%)

Method B: Boron tribromide (6 eq) was added dropwise at $-20{ }^{\circ} \mathrm{C}$ under nitrogen to a solution of 6d (or 6e) $(2 \mathrm{mmol})$ in dichlomethane $(20 \mathrm{~mL})$, then the resulting mixture was slowly warmed to room temperature and stirred overnight. Methanol $(10 \mathrm{~mL})$ was slowly added, and the mixture stirred for another $0.5 \mathrm{~h}$. The resulting mixture was evaporated and recrystallized from methanol to get yellow solid 7k (or 7l).

Detailed characterizations and spectra of all the products are described in the Supplementary Materials to this paper.

(5-Hydroxy-4-oxo-2-styryl-4H-pyridin-1-yl)-acetic acid (7a) (81\%). Purity: 98.33\%; m.p.: $254-255{ }^{\circ} \mathrm{C} ;{ }^{1} \mathrm{H}$ NMR (400 MHz, d6-DMSO) $\delta 7.66(\mathrm{~s}, 3 \mathrm{H}), 7.43(\mathrm{~m}, 3 \mathrm{H}), 7.27(\mathrm{~d}, J=2.6 \mathrm{~Hz}, 1 \mathrm{H}), 7.20(\mathrm{~d}, J=2.8,1 \mathrm{H})$, $6.83(\mathrm{~s}, 1 \mathrm{H}), 5.11(\mathrm{~s}, 2 \mathrm{H}) .{ }^{13} \mathrm{C}$ NMR (100 MHz, d6-DMSO) $\delta 169.47,168.04,146.77,146.20,136.01,127.50$, 119.30, 110.68, 55.10. HRMS (ESI) $\mathrm{m} / \mathrm{z}$ calcd. for $\mathrm{C}_{15} \mathrm{H}_{12} \mathrm{NO}_{4}{ }^{-}[\mathrm{M}-\mathrm{H}]^{-}$270.0772, found 270.0786. 
[5-Hydroxy-4-oxo-2-(2-p-tolyl-vinyl)-4H-pyridin-1-yl]-acetic acid (7b) (88\%). Purity: 99.12\%; m.p.: 256-257 ${ }^{\circ} \mathrm{C} ;{ }^{1} \mathrm{HNMR}(400 \mathrm{MHz}, d 6-\mathrm{DMSO}) \delta 8.28(\mathrm{~s}, 1 \mathrm{H}), 7.69(\mathrm{~s}, 1 \mathrm{H}), 7.63(\mathrm{~d}, J=8.7 \mathrm{~Hz}, 2 \mathrm{H}), 7.44(\mathrm{~d}, J=16.1,1 \mathrm{H})$, $7.28(\mathrm{~m}, 3 \mathrm{H}), 5.50(\mathrm{~s}, 2 \mathrm{H}), 2.35(\mathrm{~s}, 3 \mathrm{H}) .{ }^{13} \mathrm{C}$ NMR (100 MHz, d6-DMSO) $\delta 168.44,161.60,144.80,140.33$, $139.96,132.85,129.98,129.45,116.89,110.39,56.64,21.49$. HRMS (ESI) $m / z$ calcd. for $\mathrm{C}_{16} \mathrm{H}_{14} \mathrm{NO}_{4}{ }^{-}[\mathrm{M}-$ $\mathrm{H}]^{-}$284.0928, found 284.0941 .

\{2-[2-(4-tert-Butyl-phenyl)-vinyl]-5-hydroxy-4-oxo-4H-pyridin-1-yl\}-acetic acid (7c) (75\%). Purity: 98.12\%; m.p.: $241-242{ }^{\circ} \mathrm{C} ;{ }^{1} \mathrm{H}$ NMR (400 MHz, d6-DMSO) $\delta 7.56(\mathrm{~m}, 3 \mathrm{H}), 7.44(\mathrm{~d}, J=2.6 \mathrm{~Hz}, 2 \mathrm{H})$, $7.20(\mathrm{~d}, J=8.9 \mathrm{~Hz}, 1 \mathrm{H}), 7.11(\mathrm{~d}, J=8.8 \mathrm{~Hz}, 1 \mathrm{H}), 6.69(\mathrm{~s}, 1 \mathrm{H}), 5.03(\mathrm{~s}, 2 \mathrm{H}), 1.30(\mathrm{~s}, 9 \mathrm{H}) .{ }^{13} \mathrm{C}$ NMR (100 MHz, d6-DMSO) $\delta$ 169.76, 169.74, 152.37, 146.14, 136.75, 133.46, 126.02, 118.86, 110.52, 54.62, 34.95, 31.45. HRMS (ESI) $\mathrm{m} / z$ calcd. for $\mathrm{C}_{19} \mathrm{H}_{20} \mathrm{NO}_{4}^{-}[\mathrm{M}-\mathrm{H}]^{-} 326.1398$, found 326.1405 .

\{5-Hydroxy-2-[2-(4-methoxy-phenyl)-vinyl]-4-oxo-4H-pyridin-1-yl\}-acetic acid (7d) (71\%). Purity: 96.53\%; m.p.: $240-242{ }^{\circ} \mathrm{C} ;{ }^{1} \mathrm{H}$ NMR (400 MHz, d6-DMSO) $\delta 7.63(\mathrm{~m}, 3 \mathrm{H}), 7.27(\mathrm{~d}, J=16.2 \mathrm{~Hz}, 2 \mathrm{H}), 7.00(\mathrm{~m}, 2 \mathrm{H})$, $6.82(\mathrm{~s}, 1 \mathrm{H}), 6.69(\mathrm{~s}, 1 \mathrm{H}), 5.10(\mathrm{~s}, 2 \mathrm{H}), 3.80(\mathrm{~s}, 3 \mathrm{H}) .{ }^{13} \mathrm{C}$ NMR (100 MHz, d6-DMSO) $\delta 169.50,160.71$, $146.61,137.32,129.64,128.59,116.70,114.75,110.16,71.27,55.77$. HRMS (ESI) $m / z$ calcd. for $\mathrm{C}_{16} \mathrm{H}_{14} \mathrm{NO}_{5}{ }^{-}$ $[\mathrm{M}-\mathrm{H}]^{-}$300.0877, found 300.0874.

\{2-[2-(3,4-Dimethoxy-phenyl)-vinyl]-5-hydroxy-4-oxo-4H-pyridin-1-yl\}-acetic acid (7e) (80\%). Purity: 95.84\%; m.p.: $220-222{ }^{\circ} \mathrm{C} ;{ }^{1} \mathrm{H}$ NMR $(400 \mathrm{MHz}, d 6-\mathrm{DMSO}) \delta 7.71(\mathrm{~d}, J=2.2 \mathrm{~Hz}, 1 \mathrm{H}), 7.53-7.42(\mathrm{~m}, 4 \mathrm{H}), 7.23(\mathrm{~d}$, $J=2.1 \mathrm{~Hz}, 2 \mathrm{H}), 6.66(\mathrm{~s}, 1 \mathrm{H}), 5.18(\mathrm{~s}, 2 \mathrm{H}), 3.89(\mathrm{~s}, 3 \mathrm{H}), 3.84(\mathrm{~s}, 3 \mathrm{H}) .{ }^{13} \mathrm{C}$ NMR $(100 \mathrm{MHz}, d 6-\mathrm{DMSO}) \delta$ 168.44, 163.00, 159.70, 149.41, 145.04, 135.86, 135.46, 131.42, 130.81, 116.74, 115.40, 106,76, 98.91, 71.96, 56.32, 56.04. HRMS (ESI) $\mathrm{m} / \mathrm{z}$ calcd. for $\mathrm{C}_{17} \mathrm{H}_{16} \mathrm{NO}_{6}{ }^{-}[\mathrm{M}-\mathrm{H}]^{-}$330.0983, found 330.0979.

\{2-[2-(4-Fluoro-phenyl)-vinyl]-5-hydroxy-4-oxo-4H-pyridin-1-yl\}-acetic acid (7f) (87\%). Purity: 99.19\%; m.p.: 262-263 ${ }^{\circ} \mathrm{C} ;{ }^{1} \mathrm{H}$ NMR (400 MHz, d6-DMSO) $\delta 7.71(\mathrm{~m}, 2 \mathrm{H}), 7.49(\mathrm{~s}, 1 \mathrm{H}), 7.25(\mathrm{~m}, 3 \mathrm{H}), 7.12(\mathrm{~m}, 1 \mathrm{H}), 6.61$ $(\mathrm{s}, 1 \mathrm{H}), 4.99$ (s, 2H). ${ }^{13} \mathrm{C}$ NMR (100 MHz, d6-DMSO) $\delta 170.76,169.91,164.10,161.65,147.57,145.80$, $135.29,130.01,129.93,125.17,116.06,110.62,54.34$. HRMS (ESI) $\mathrm{m} / z$ calcd. for $\mathrm{C}_{15} \mathrm{H}_{11} \mathrm{FNO}_{4}{ }^{-}\left[\mathrm{M}-\mathrm{H}^{-}\right.$ 288.0678 , found 288.0677 .

\{2-[2-(3,4-Difluoro-phenyl)-vinyl]-5-hydroxy-4-oxo-4H-pyridin-1-yl\}-acetic acid (7g) (74\%). Purity: 98.57\%; m.p.: $255-256{ }^{\circ} \mathrm{C} ;{ }^{1} \mathrm{H}$ NMR (400 MHz, d6-DMSO) $\delta 7.86(\mathrm{dd}, J=8.1,2.2 \mathrm{~Hz}, 1 \mathrm{H}), 7.50(\mathrm{~s}, 1 \mathrm{H}), 7.33$ $(\mathrm{t}, J=8.1 \mathrm{~Hz}, 1 \mathrm{H}), 7.16(\mathrm{~m}, 3 \mathrm{H}), 6.58(\mathrm{~s}, 1 \mathrm{H}), 4.95(\mathrm{~s}, 2 \mathrm{H}) .{ }^{13} \mathrm{C}$ NMR $(100 \mathrm{MHz}, d 6-\mathrm{DMSO}) \delta 170.76$, $169.83,147.70,145.54,130.50,125.21,122.62,120.71,110.92,104.92,54.37$. HRMS (ESI) $\mathrm{m} / \mathrm{z}$ calcd. for $\mathrm{C}_{15} \mathrm{H}_{10} \mathrm{~F}_{2} \mathrm{NO}_{4}^{-}[\mathrm{M}-\mathrm{H}]^{-}$306.0583, found 306.0587.

\{5-Hydroxy-4-oxo-2-[2-(4-trifluoromethyl-phenyl)-vinyl]-4H-pyridin-1-yl\}-acetic acid (7h) (83\%). Purity: 97.80\%; m.p.: $267-268{ }^{\circ} \mathrm{C} ;{ }^{1} \mathrm{H}$ NMR (400 MHz, d6-DMSO) $\delta 8.34(\mathrm{~s}, 1 \mathrm{H}), 7.97(\mathrm{~d}, J=2.4 \mathrm{~Hz}, 2 \mathrm{H})$, $7.84(\mathrm{~d}, J=2.2 \mathrm{~Hz}, 2 \mathrm{H}), 7.75(\mathrm{~s}, 1 \mathrm{H}), 7.57(\mathrm{~d}, J=2.1 \mathrm{~Hz}, 2 \mathrm{H}), 5.55(\mathrm{~s}, 2 \mathrm{H}) .{ }^{13} \mathrm{C}$ NMR $(100 \mathrm{MHz}, d 6-\mathrm{DMSO})$ $\delta 168.38,161.34,146.36,145.13,138.32,129.06,126.24,123.19,120.78,111.05,56.84$. HRMS (ESI) $\mathrm{m} / \mathrm{z}$ calcd. for $\mathrm{C}_{16} \mathrm{H}_{11} \mathrm{~F}_{3} \mathrm{NO}_{4}^{-}[\mathrm{M}-\mathrm{H}]^{-} 338.0646$, found 338.0638.

\{5-Hydroxy-2-[2-(4-methanesulfonyl-phenyl)-vinyl]-4-oxo-4H-pyridin-1-yl\}-acetic acid (7i) (82\%). Purity: 99.02\%; m.p.: $275-277^{\circ} \mathrm{C}$; ${ }^{1} \mathrm{H}$ NMR (400 MHz, d6-DMSO) $\delta 8.24(\mathrm{~s}, 1 \mathrm{H}), 8.00(\mathrm{~d}, J=2.4 \mathrm{~Hz}, 4 \mathrm{H})$, $7.61(\mathrm{~s}, 1 \mathrm{H}), 7.56(\mathrm{~s}, 2 \mathrm{H}), 5.49(\mathrm{~s}, 2 \mathrm{H}), 3.26(\mathrm{~s}, 3 \mathrm{H}) .{ }^{13} \mathrm{C}$ NMR $(100 \mathrm{MHz}, d 6-\mathrm{DMSO}) \delta 168.45,161.87$, 145.36, 141.63, 140.41, 137.88, 129.06, 127.96, 121.57, 111.15, 56.75, 43.93. HRMS (ESI) $\mathrm{m} / \mathrm{z}$ calcd. for $\mathrm{C}_{16} \mathrm{H}_{14} \mathrm{NO}_{6} \mathrm{~S}^{-}[\mathrm{M}-\mathrm{H}]^{-}$348.0547, found 348.0548.

\{2-[2-(4-Amino-phenyl)-vinyl]-5-hydroxy-4-oxo-4H-pyridin-1-yl\}-acetic acid (7j) (71\%). Purity: 99.10\%; m.p.: 222-224 ${ }^{\circ} \mathrm{C} ;{ }^{1} \mathrm{H}$ NMR $(400 \mathrm{MHz}, d 6-\mathrm{DMSO}) \delta 8.15(\mathrm{~s}, 1 \mathrm{H}), 7.58(\mathrm{~s}, 1 \mathrm{H}), 7.48(\mathrm{~d}, J=2.6 \mathrm{~Hz}, 2 \mathrm{H}), 7.32$ $(\mathrm{d}, J=8.7 \mathrm{~Hz}, 1 \mathrm{H}), 6.96(\mathrm{~d}, J=8.9 \mathrm{~Hz}, 1 \mathrm{H}), 6.70(\mathrm{~d}, J=2.2 \mathrm{~Hz}, 2 \mathrm{H}), 5.41(\mathrm{~s}, 2 \mathrm{H}) .{ }^{13} \mathrm{C}$ NMR $(100 \mathrm{MHz}$, $d 6$-DMSO) $\delta 169.02,161.95,150.37,148.41,144.59,141.18,132.13,130.71,124.56,115.52,112.06,109.60$, 56.78. HRMS (ESI) $\mathrm{m} / z$ calcd. for $\mathrm{C}_{15} \mathrm{H}_{13} \mathrm{~N}_{2} \mathrm{O}_{4}{ }^{-}[\mathrm{M}-\mathrm{H}]^{-}$285.0881, found 285.0879. 
\{5-Hydroxy-2-[2-(4-hydroxy-phenyl)-vinyl]-4-oxo-4H-pyridin-1-yl\}-acetic acid (7k) (32\%). Purity: 95.14\%; m.p.: $211-212{ }^{\circ} \mathrm{C} ;{ }^{1} \mathrm{H}$ NMR (400 MHz, d6-DMSO) $\delta 12.19(\mathrm{~s}, 1 \mathrm{H}), 9.80(\mathrm{~s}, 1 \mathrm{H}), 8.40(\mathrm{~d}, J=2.1 \mathrm{~Hz}, 1 \mathrm{H})$, $8.23(\mathrm{~s}, 1 \mathrm{H}), 7.95(\mathrm{~d}, J=2.2 \mathrm{~Hz}, 1 \mathrm{H}), 7.71(\mathrm{~s}, 1 \mathrm{H}), 7.49(\mathrm{~d}, J=8.7 \mathrm{~Hz}, 1 \mathrm{H}), 6.97(\mathrm{~m}, 2 \mathrm{H}), 6.43(\mathrm{~s}, 1 \mathrm{H}), 5.02$ (s, 2H). ${ }^{13} \mathrm{C}$ NMR (100 MHz, d6-DMSO) $\delta 169.03,159.48,148.79,146.14,143.77,136.46,128.93,128.73$, 117.01, 116.25. 106.60, 98.91, 56.24. HRMS (ESI) $\mathrm{m} / z$ calcd. for $\mathrm{C}_{15} \mathrm{H}_{12} \mathrm{NO}_{5}{ }^{-}[\mathrm{M}-\mathrm{H}]^{-} 286.0721$, found 286.0708 .

\{2-[2-(3,4-Dihydroxy-phenyl)-vinyl]-5-hydroxy-4-oxo-4H-pyridin-1-yl\}-acetic acid (71) (29\%). Purity: 96.21\%; m.p. $>300{ }^{\circ} \mathrm{C} ;{ }^{1} \mathrm{H}$ NMR $(400 \mathrm{MHz}$, d6-DMSO) $\delta 8.19(\mathrm{~s}, 1 \mathrm{H}), 8.13(\mathrm{~s}, 1 \mathrm{H}), 7.83(\mathrm{~d}, J=2.1 \mathrm{~Hz}, 1 \mathrm{H}), 7.79$ $(\mathrm{m}, 2 \mathrm{H}), 7.68(\mathrm{~s}, 1 \mathrm{H}), 6.93(\mathrm{~d}, J=8.1 \mathrm{~Hz}, 1 \mathrm{H}), 4.99(\mathrm{~s}, 2 \mathrm{H}) .{ }^{13} \mathrm{C}$ NMR $(100 \mathrm{MHz}, d 6-\mathrm{DMSO}) \delta 178.80$, $161.02,152.94,145.45,135.27,126.13,125.75,116.26,116.14,105.49,104.03,103.94,56.88$. HRMS (ESI) $\mathrm{m} / \mathrm{z}$ calcd. for $\mathrm{C}_{15} \mathrm{H}_{12} \mathrm{NO}_{6}{ }^{-}[\mathrm{M}-\mathrm{H}]^{-} 302.0670$, found 302.0687 .

\subsection{Enzyme Inhibition Assays}

The ALR2 inhibition activity was evaluated in a mixture of reaction with $50 \mu \mathrm{L}$ NADPH $(0.1 \mathrm{mM})$, $50 \mu \mathrm{L}$ sodium phosphate buffer $(\mathrm{pH}=6.2,100 \mathrm{mM}), 50 \mu \mathrm{L}$ human recombinant ALR2, $1 \mu \mathrm{L}$ dimethyl sulfoxide (DMSO) as solvent, and $50 \mu \mathrm{L} \mathrm{D,L-glyceraldehyde}(10 \mathrm{mM})$ which served as a substrate. Although L-idose, which enable the transformation of ALR2, was an essential substrate for assays evaluating differential inhibitors, D,L-glyceraldehyde was used here to disclose classical inhibitors that interact as strongly as possible with the residues at the active site [41]. Before the substrate was added, the mixture was incubated at $30^{\circ} \mathrm{C}$ for $3 \mathrm{~min}$, then the reaction was started when the substrate was added, and was monitored for $4 \mathrm{~min}$. The ALR1 inhibition activity experiment was conducted at $37^{\circ} \mathrm{C}$ in the mixture containing $50 \mu \mathrm{L}$ NADPH $(0.12 \mathrm{mM}), 50 \mu \mathrm{L}$ human recombinant ALR1, $50 \mu \mathrm{L}$ sodium phosphate buffer $(\mathrm{pH}=7.2,100 \mathrm{mM}), 50 \mu \mathrm{L}$ sodium D-gluconate $(20 \mathrm{mM})$ as a substrate, and $1 \mu \mathrm{L}$ DMSO as solvent. Before the substrate sodium D-gluconate was added, the mixture was incubated at $37^{\circ} \mathrm{C}$ for $3 \mathrm{~min}$, then the substrate was added to start the reaction, which was monitored for $4 \mathrm{~min}$.

The inhibitory activities of the title synthetic compounds against ALR2 and ALR1 were examined by adding $1 \mu \mathrm{L}$ of the inhibitor solution to the ALR2 or ALR1 mixtures. All compounds were dissolved in DMSO, and the solutions were diluted with DMSO to desirable concentrations. To correct for the nonenzymatic oxidation of NADPH, the rate of NADPH oxidation in the presence of all of the reaction mixture components except the substrate was subtracted from each experimental rate. The title compounds were tested at concentrations ranging from $100 \mu \mathrm{M}$ to $1 \mu \mathrm{M}$, except compound 71 which were tested $10 \mu \mathrm{M}$ to $0.1 \mu \mathrm{M}$. Epalrestat was tested at concentration from $1 \mu \mathrm{M}$ to $0.01 \mu \mathrm{M}$. The inhibitory rates of tested compounds were calculated by equation as follows:

$$
\begin{gathered}
\text { Inhibitory rate }(\%)=\left(1-\Delta \mathrm{A}_{\text {sample }} / \Delta \mathrm{A}_{\mathrm{E}+\mathrm{DMSO}}\right) \times 100 \% \\
\text { sample }=\text { enzyme }+ \text { compound }+\mathrm{DMSO} \\
\mathrm{E}+\mathrm{DMSO}=\text { enzyme }+\mathrm{DMSO}
\end{gathered}
$$

As shown in Figure 3, most dose-response curves were generated using at least three concentrations of the compound with inhibitory rate, and the $\mathrm{IC}_{50}$ values were calculated by least-square analysis of the linear portion of the $\log ($ dose $)$ versus response curves $\left(\mathrm{r}^{2}>0.95\right)$, with equation $\mathrm{IC}_{50}(\mu \mathrm{M})=10^{\mathrm{x}}+6$. The experiments were performed in triplicate. 


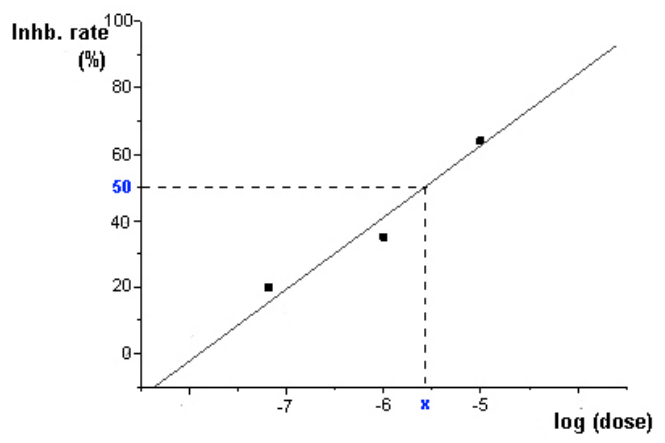

Figure 3. Exemplary dose-response curves for calculating $\mathrm{IC}_{50}$ values.

\subsection{Antioxidant Assays}

Antioxidant assays were performed with the similar protocol as described previously [42].

\subsection{Molecular Docking Assay}

Molecular docking was performed utilizing Molegro Virtual Docker, version 6.0 with standard procedure [22,42]. The crystal structure of hALR2 conjugated with lidorestat (PDB code: 1Z3N) [38] and pure structure of hALR1 (PDB code: 1ZUA) [40] were downloaded from the RCSB Protein Data Bank to evaluate the binding mode of the derivatives. All solvent molecules within the protein document were deleted, and NADPH was set as cofactor. All 3D structural parameters of ligands were input into Molegro Virtual Docker software. The cavities were detected by Expanded Van der Waals around the enzyme surface, and cavity 1 , which contained the anion binding site (volume of $\sim 65 \mathrm{~A}$ ), was selected for the origin of docking grid. The grid radius was set to 14 . All the calculations were carried out by the grid-based MolDock score (GRID) function with a grid resolution of $0.20 \mathrm{~A}$. The best ligand poses were chosen on the basis of ReRank score. The binding energy and inhibitory constant were calculated by the software. These docking assays were performed with a dual processor Windows 7 based computer with 4 GB RAM, and each docking process took 2-3 min.

\section{Conclusions}

To much effectively retard the long-term diabetic complications, antioxidative 5-hydroxy-2-styryl-1H-pyridin-4-ones-based derivatives were designed for a combination of selective ALR2 inhibition and antioxidant. Significantly, most of the synthetic 7 with styryl residues showed a good inhibitory activity, and some exhibited fine selectivity towards ALR2 and antioxidant activity. In addition, the results concluded from structure-activity relationship analysis combined with further molecular docking studies revealed that the substitution greatly altered inhibitory action of the derivatives. Substituted by alkine groups, hydroxyl groups and F atoms in the aromatic rings of the side chains, the inhibitory efficacy was enhanced dramatically; however, electronic-withdrawing groups, especially the methanesulfonyl group, decreased the potency. Particularly, molecular modeling study revealed that 71 not only totally blocked the anion pocket but also strongly interacted with specificity pocket, proving that 71 , of which $\mathrm{IC}_{50}(0.789 \mu \mathrm{M})$ was lowest among the derivatives, inhibited ALR2 much vigorously. More significantly, 71 were found to be more active than conventional antioxidant Trolox, with DPPH radicals scavenging rate $41.48 \%(1 \mu \mathrm{M})$ and lipid peroxidation suppressing rate $88.76 \%(100 \mu \mathrm{M})$, suggesting that 71 could favorably reduce the level of oxidative stress. In this study, antioxidant structure of 5-hydroxyl pyridinone was utilized to design novel multifunctional ALR2 inhibitors. As a result, compound 71 represented potent leads for the achievement of the inhibitors possessing both capacities for ALR2 inhibition and as antioxidant.

Supplementary Materials: The following are available online at Figures S1-S24: NMR specta of title compounds, Figures S25-S36: HRMS specta of title compounds, Figures S36-S48: UV-vis specta of title compounds. 
Author Contributions: Conceptualization, H.C. and B.M.; methodology, H.C.; software, X.Z. (Xin Zhang) and X.Z. (Xiaonan Zhang); validation, Y.L., W.L. and C.Z.; formal analysis, H.C.; investigation, H.C.; data curation, H.C. and X.Z. (Xiaonan Zhang); writing-original draft preparation, H.C.; writing-review and editing, H.C.; visualization, C.Z.; supervision, B.M.; project administration, B.M.; funding acquisition, C.Z. All authors have read and agreed to the published version of the manuscript.

Funding: This research was funded by the National Natural Science Foundation of China, grant number 21272025.

Acknowledgments: The authors would like to thank Analysis \& Testing Center, Beijing Institute of Technology for technical support for performing in the structural analysis of synthetic compounds.

Conflicts of Interest: The authors declare no conflict of interest.

\section{References}

1. Cosconati, S.; Marinelli, L.; Motta, C.L.; Sartini, S.; Settimo, F.D.; Olson, A.J.; Novellino, E. Pursuing aldose reductase inhibitors through in situ cross-docking and similarity-based virtual screening. J. Med. Chem. 2009, 52, 5578-5581. [CrossRef]

2. Gabbay, K.H.; Merola, L.O.R.; Field, A. Sorbitol pathway: Presence in nerve and cord with substrate accumulation in diabetes. Science 1966, 151, 209-210. [CrossRef]

3. Srivastava, S.K.; Ramana, K.V.; Bhatnagar, A. Role of aldose reductase and oxidative damage in diabetes and the consequent potential for therapeutic options. Endocr. Rev. 2005, 26, 380-392. [CrossRef]

4. Alexiou, P.; Pegklidou, K.; Chatzopoulou, M.; Nicolaou, I.; Demopoulos, V. Aldose reductase enzyme and its implication to major health problems of the 21st century. J. Curr. Med. Chem. 2009, 16, 734-752. [CrossRef] [PubMed]

5. Brownlee, M. The pathobiology of diabetic complications: A unifying mechanism. Diabetes 2005, 54, 1615-1625. [CrossRef] [PubMed]

6. Kinoshita, J.H.; Nishimura, C. The involvement of aldose reductase in diabetic complications. Diabetes Metab. Rev. 1988, 4, 323-337. [CrossRef] [PubMed]

7. Chung, S.S.; Chung, S.K. Genetic analysis of aldose reductase in diabetic complications. Curr. Med. Chem. 2003, 10, 1375-1387. [CrossRef] [PubMed]

8. Gabbay, K.H.N. The sorbitol pathway and the complications of diabetes. Engl. J. Med. 1973, 288, 831-836. [CrossRef]

9. Brownlee, M. Biochemistry and molecular cell biology of diabetic complications. Nature 2001, 414, 813-820. [CrossRef] [PubMed]

10. Hers, H.G. Le mécanisme de la transformation de glucose en fructose par les vésicules séminales. Biochim. Biophys. Acta. 1956, 22, 202-203. [CrossRef]

11. Suzen, S.; Buyukbingol, E. Recent studies of aldose reductase enzyme inhibition for diabetic complications. Curr. Med. Chem. 2003, 10, 1329-1352. [CrossRef]

12. El-Kabbani, O.; Darmanin, C.; Schneider, T.R.; Hazemann, I.; Ruiz, F.M.; Oka, M.; Joachimiak, A.; Schulze-Briese, C.; Tomizaki, T.; Mitschler, A.; et al. Ultrahigh resolution drug design. II. Atomic resolution structures of human aldose reductase holoenzyme complexed with fidarestat and minalrestat: Implications for the binding of cyclic imide inhibitors. Proteins 2004, 55, 805-813. [CrossRef]

13. Nishikawa, T.; Edelstein, D.; Brownlee, M. A single unifying mechanism for diabetic complications. Kidney Int. 2000, 58, S26-S30. [CrossRef] [PubMed]

14. Rui, H.L.; Hotchkiss, J.H. Potential genotoxicity of chronically elevated nitric oxide: A review. Mutat. Res. 1995, 339, 73-89. [CrossRef]

15. Vajragupta, O.; Boonchoong, P.; Berliner, L.J. Manganese complexes of curcumin analogues: Evaluation of hydroxyl radical scavenging ability, superoxide dismutase activity and stability towards hydrolysis. Free Radical Res. 2004, 38, 303-314. [CrossRef]

16. Vincent, A.M.; Russell, J.W.; Low, P.; Feldman, E.L. Oxidative stress in the pathogenesis of diabetic neuropathy. Endocr. Rev. 2004, 25, 612-628. [CrossRef] [PubMed]

17. Bohren, K.M.; Grimshaw, C.E.; Gabbay, K.H. Stable expression of chicken type-VI collagen $\alpha 1, \alpha 2$ and $\alpha 3$ cDNAs in murine NIH/3T3 cells. J. Biol. Chem. 1992, 209, 785-792. [CrossRef]

18. El-Kabbani, O.; Podjarny, A. Selectivity determinants of the aldose and aldehyde reductase inhibitor-binding sites. Cell. Mol. Life Sci. 2007, 64, 1970-1978. [CrossRef] 
19. Balestri, F.; Cappiello, M.; Moschini, R.; Rotondo, R.; Abate, M.; Del-Corso, A.; Mura, U. Modulation of aldose reductase activity by aldose hemiacetals. BBA-Gen. Subj. 2015, 1850, 2329-2339. [CrossRef]

20. Kucerova-Chlupacova, M.; Halakova, D.; Majekova, M.; Treml, J.; Stefek, M.; Prnova, M.S. (4-Oxo-2-thioxothiazolidin-3-yl)acetic acids as potent and selective aldose reductase inhibitors. Chem.-Biol Interact. 2020, 332, 109286. [CrossRef] [PubMed]

21. Celestina, S.K.; Sundaram, K.; Ravi, S. In vitro studies of potent aldose reductase inhibitors: Synthesis, characterization, biological evaluation and docking analysis of rhodanine-3-hippuric acid derivatives. Bioorg. Chem. 2020, 97, 103640. [CrossRef]

22. Hao, X.; Qi, G.; Ma, H.; Zhu, C.; Han, Z. Novel 2-phenoxypyrido[3,2-b]pyrazin-3(4H)-one derivatives as potent and selective aldose reductase inhibitors with antioxidant activity. J. Enzym. Inhib. Med. Ch. 2019, 34, 1368-1372. [CrossRef] [PubMed]

23. Hlavac, M.; Kovacikova, L.; Prnova, M.S.; Šramel, P.; Addova, G.; Majekova, M.; Hanquet, G.; Bohac, A.; Stefek, M. Development of Novel Oxotriazinoindole Inhibitors of Aldose Reductase: Isosteric Sulfur/Oxygen Replacement in the Thioxotriazinoindole Cemtirestat Markedly Improved Inhibition Selectivity. J. Med. Chem. 2020, 63, 369-381. [CrossRef]

24. Carlo, G. Depigmenting Compositions. WO 20010117497A1, 15 March 2001. Available online: https: //patents.google.com/patent/WO2001017497A1/en (accessed on 5 October 2020).

25. Cohen, S.M.; Credille, C.V.; Puerta, D.T. Compositions and methods for inhibiting influenza RNA polymerase endonuclease. U.S. Patent 2019106398, 11 April 2019.

26. Zou, C.B.; Liu, X.G.; Xie, R.J.; Bao, Y.S.; Jin, Q.; Jia, X.B.; Li, L.; Liu, R.C. Deferiprone attenuates inflammation and myocardial fibrosis in diabetic cardiomyopathy rats. Biochem. Bioph. Res. Co. 2017, 486, 930-936. [CrossRef]

27. Zhao, D.Y.; Zhang, M.X.; Dong, X.W.; Hu, Y.Z.; Dai, X.Y.; Wei, X.Y.; Hider, R.C.; Zhang, J.C.; Zhou, T. Design and synthesis of novel hydroxypyridinone derivatives as potential tyrosinase inhibitors. Bioorg. Med. Chem. Lett. 2016, 26, 3103-3108. [CrossRef] [PubMed]

28. Taylor, P.D. Solution chemistry of vanadium-(IV) and-(V) with the bidentate ligand 1, 2-dimethyl-3-hydroxy-4 (1H)-pyridinone: Relevance to the treatment of diabetes. Chem. Commun. 1996, 3, 405-406. [CrossRef]

29. Katoh, A.; Yamaguchi, M.; Taguchi, K.; Saito, R.; Adachi, Y.; Yoshikawa, Y.; Sakurai, H. Oxovanadium (IV) and (V) Complexes with 3-Hydroxy-4 (1H)-pyridinones and 1-Hydroxy-2 (1H)-pyrimidinones-Synthesis, Structural Characteristics, and Their Insulin-mimetic Activities. Biomed. Res. Trace Elem. 2006, 17, 1-10.

30. Rangel, M.; Tamura, A.; Fukushima, C.; Sakurai, H. In vitro study of the insulin-like action of vanadyl-pyrone and-pyridinone complexes with a VO (O 4) coordination mode. J. Biol. Inorg. Chem. 2001, 6, 128-132. [CrossRef]

31. Kontoghiorghe, C.N. Antioxidant targeting by deferiprone in diseases related to oxidative damage. Front Biosci. 2014, 19, 862-885. [CrossRef]

32. Bebbington, D.; Gaur, S. 3-Hydroxy-2(1H)-pyridinone or 3-hydroxy-4(1H)-pyridinone Derivatives Useful as Reactive Oxygen Species (ROS) Scavengers. EP1006112A1, 7 June 2000. Available online: https: //patents.google.com/patent/EP1006112A1/en (accessed on 5 October 2020).

33. Chen, T.D.; Ko, J.H.; Prendecki, M.; McAdoo, S.P.; Pusey, C.D.; Cook, H.T.; Behmoaras, J. Deferiprone, an iron chelator, is preventive and therapeutic in experimental crescentic glomerulonephritis. bioRxiv 2017, 225540. Available online: https://www.biorxiv.org/content/10.1101/225540v1.article-info (accessed on 27 November 2017). [CrossRef]

34. Xu, P.; Zhang, M.; Sheng, R.; Ma, Y. Synthesis and biological evaluation of deferiprone-resveratrol hybrids as antioxidants, A $1-42$ aggregation inhibitors and metal-chelating agents for Alzheimer's disease. Eur. J. Med. Chem. 2017, 127, 174-186. [CrossRef]

35. Iqbal, Z.; Morahan, G.; Arooj, M.; Sobolev, A.N.; Hameed, S. Synthesis of new arylsulfonylspiroimidazolidine- $2^{\prime}, 4^{\prime}$-diones and study of their effect on stimulation of insulin release from MIN6 cell line, inhibition of human aldose reductase, sorbitol accumulations in various tissues and oxidative stress. Eur. J. Med. Chem. 2019, 168, 154-175. [CrossRef] [PubMed]

36. Lewis, F.W.; Fairooz, S.; Elson, J.L.; Hubscher-Bruder, V.; Brandel, J.; Soundararajan1, M.; Smith, D.; Dexter, D.T.; Tétard, D.; Pienaar, I.S. Novel 1-hydroxypyridin-2-one metal chelators prevent and rescue ubiquitin proteasomal-related neuronal injury in an in vitro model of Parkinson's disease. Arch. Toxicol. 2020, 94, 813-831. [CrossRef] 
37. Chaves, S.; Canário, S.; Carrasco, M.P.; Mira, L.; Santos, M.A. Hydroxy(thio)pyrone and hydroxy(thio)pyridinone iron chelators: Physico-chemical properties and anti-oxidant activity. J. Inorg. Biochem. 2012, 114, 38-46. [CrossRef]

38. El-Kabbani, O.; Carbone, V.; Darmanin, C.; Oka, M.; Mitschler, A.; Podjarny, A.; Schulze-Briese, C.; Chung, R.P. Structure of aldehyde reductase holoenzyme in complex with the potent aldose reductase inhibitor fidarestat: implications for inhibitor binding and selectivity. J. Med. Chem. 2005, 48, 5536-5542. [CrossRef]

39. Costantino, L.; Ferrari, A.M.; Gamberini, M.C.; Rastelli, G. Nitrophenyl derivatives as aldose reductase inhibitors. Bioorg. Med. Chem. 2002, 10, 3923-3931. [CrossRef]

40. Gallego, O.; Ruiz, F.X.; Ardèvol, A.; Domínguez, M.; Alvarez, R.; Lera, A.R.; Rovira, C.; Farrés, J.; Fita, I.; Parés, X. Structural basis for the high all-trans-retinaldehyde reductase activity of the tumor marker AKR1B10. Proc. Natl. Acad. Sci. USA 2007, 104, 20764-20769. [CrossRef] 
41. Cappiello, M.; Balestri, F.; Moschini, R.; Mura, U.; Del-Corso, A. Intra-site differential inhibition of multi-specific enzymes. J. Enzym. Inhib. Med. Chem. 2020, 35, 840-846. [CrossRef]

42. Qin, X.Y.; Hao, X.; Han, H.; Zhu, S.J.; Yang, Y.C.; Wu, B.B.; Hussain, S.; Parveen, S.; Jing, C.J.; Ma, B. Design and synthesis of potent and multifunctional aldose reductase inhibitors based on quinoxalinones. J. Med. Chem. 2015, 58, 1254-1267. [CrossRef]

Sample Availability: Samples of the compounds 7a-1 are available from the authors.

Publisher's Note: MDPI stays neutral with regard to jurisdictional claims in published maps and institutional affiliations.

(C) 2020 by the authors. Licensee MDPI, Basel, Switzerland. This article is an open access article distributed under the terms and conditions of the Creative Commons Attribution (CC BY) license (http://creativecommons.org/licenses/by/4.0/). 